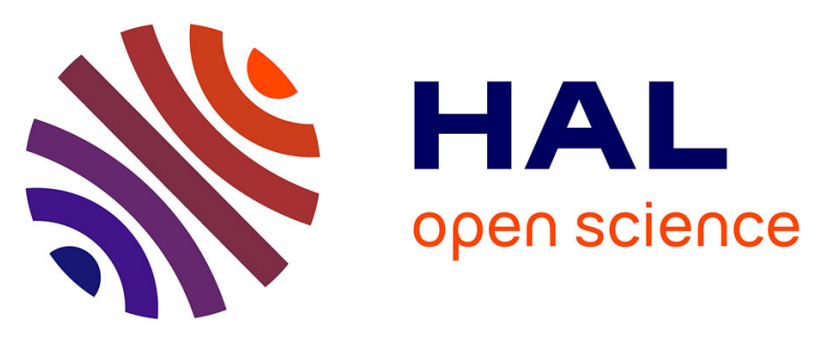

\title{
Effect of the niobium state on the properties of NbSiBEA as bifunctional catalysts for gas- and liquid-phase tandem processes
}

Pavlo I. Kyriienko, Olga V. Larina, Nataliia O. Popovych, Sergiy O. Soloviev, Yannick Millot, Stanislaw Dzwigaj

\section{To cite this version:}

Pavlo I. Kyriienko, Olga V. Larina, Nataliia O. Popovych, Sergiy O. Soloviev, Yannick Millot, et al. Effect of the niobium state on the properties of NbSiBEA as bifunctional catalysts for gas- and liquid-phase tandem processes. Journal of Molecular Catalysis A: Chemical, 2016, 424, pp.27-36. 10.1016/j.molcata.2016.06.024 . hal-01346172

\section{HAL Id: hal-01346172 \\ https://hal.sorbonne-universite.fr/hal-01346172}

Submitted on 18 Jul 2016

HAL is a multi-disciplinary open access archive for the deposit and dissemination of scientific research documents, whether they are published or not. The documents may come from teaching and research institutions in France or abroad, or from public or private research centers.
L'archive ouverte pluridisciplinaire HAL, est destinée au dépôt et à la diffusion de documents scientifiques de niveau recherche, publiés ou non, émanant des établissements d'enseignement et de recherche français ou étrangers, des laboratoires publics ou privés. 


\section{Effect of the niobium state on the properties of NbSiBEA as bifunctional catalysts for gas- and liquid-phase tandem processes}

Pavlo I. Kyriienko a,*, Olga V. Larina ${ }^{\mathrm{a}}$, Nataliia O. Popovych ${ }^{\mathrm{a}}$, Sergiy O. Soloviev ${ }^{\mathrm{a}}$, Yannick Millot ${ }^{\mathrm{b}}$, Stanislaw Dzwigaj ${ }^{\mathrm{b}, *}$

${ }^{a}$ L.V.Pisarzhevsky Institute of Physical Chemistry of the NAS of Ukraine

31 Prosp. Nauky, 03028 Kyiv, Ukraine

b Sorbonne Universités, UPMC Univ Paris 06, CNRS, UMR 7197, Laboratoire de Réactivité de Surface, F-75005, Paris, France

* Corresponding authors:

Pavlo I. Kyriienko, e-mail address: pavlo_kyriienko@,ukr.net

Stanislaw Dzwigaj, e-mail address: stanislaw.dzwigaj@upmc.fr 


\section{Graphical Abstract}

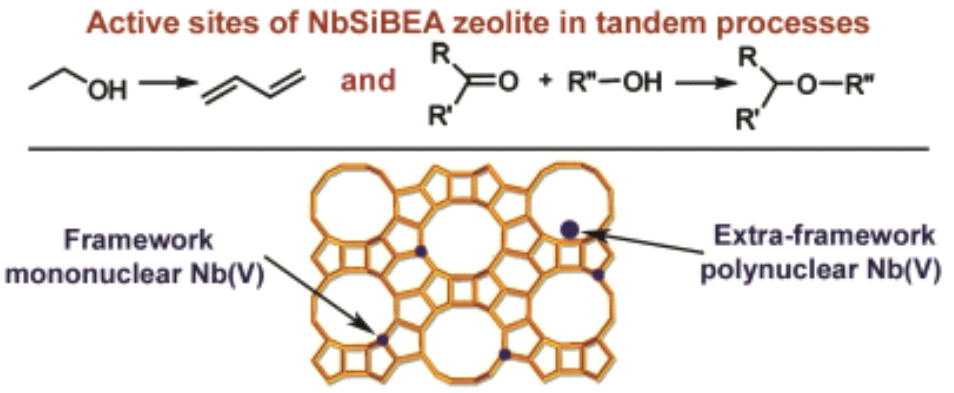




\title{
Highlights
}

Mononuclear and polynuclear $\mathrm{Nb}(\mathrm{V})$ were identified in $\mathrm{NbSiBEA}$ zeolites.

The state of niobium in NbSiBEA zeolite determined its catalytic properties.

Higher TOF and TON values were achieved on NbSiBEA with framework mononuclear $\mathrm{Nb}(\mathrm{V})$.

Bifunctional catalyst for tandem processes was designed using two-step postsynthesis method.

\begin{abstract}
NbSiBEA zeolites contained isolated framework mononuclear $\mathrm{Nb}(\mathrm{V})\left(\mathrm{Nb}_{0.7} \mathrm{SiBEA}\right)$ and a mixture of framework mononuclear and extra-framework polynuclear $\mathrm{Nb}(\mathrm{V})\left(\mathrm{Nb}_{2.0} \mathrm{SiBEA}\right)$ were prepared by two-step postsynthesis method as evidenced by XRD, NMR, DR UV-vis and FTIR. DR UV-vis showed that two types of framework mononuclear $\mathrm{Nb}(\mathrm{V})$ are present in $\mathrm{Nb}_{0.7} \mathrm{SiBEA}$, while $\mathrm{Nb}_{2.0}$ SiBEA mainly contained isolated mononuclear $\mathrm{Nb}(\mathrm{V})$ in the framework of zeolite and polynuclear $\mathrm{Nb}(\mathrm{V})$ in the extra-framework position. FTIR with pyridine and 2,6-di-tertbutylpyridine as probe molecules showed that major amount Lewis and weak Brønsted acidic sites are formed by incorporation of niobium in the framework of zeolites as mononuclear $\mathrm{Nb}(\mathrm{V})$. The catalytic properties of $\mathrm{Nb}$-containing zeolites were investigated in tandem processes of ethanol conversion into 1,3-butadiene (gas-phase) and synthesis of unsymmetrical ethers from aromatic aldehyde and aliphatic alcohol (liquid-phase). It has been found that $\mathrm{Nb}_{0.7} \mathrm{SiBEA}$ catalyst, containing only isolated framework mononuclear $\mathrm{Nb}(\mathrm{V})$ is more active than $\mathrm{Nb}_{2.0} \mathrm{SiBEA}$ in the conversion of ethanol and ethanol/acetaldehyde mixture into 1,3-butadiene, MPV reduction of crotonaldehyde with ethanol and etherification of 4-methoxybenzyl alcohol with 2-butanol. The higher specific activity (turnover number/frequency) of $\mathrm{Nb}_{0.7} \mathrm{SiBEA}$ than $\mathrm{Nb}_{2.0} \mathrm{SiBEA}$ catalyst has been revealed for gas- and liquid-phase tandem processes.
\end{abstract}

Keywords: niobium, zeolite, acidic sites, framework sites, tandem processes 


\section{Introduction}

Niobium-containing materials are widely studied as solid catalysts for heterogeneous processes including sustainable organic synthesis [1]. $\mathrm{Nb}_{2} \mathrm{O}_{5} / \mathrm{SiO}_{2}$ catalysts are active in sugar dehydration [2-5], methanol oxidation [6], glycerol dehydration to acrolein [7] and oxidation reactions with aqueous $\mathrm{H}_{2} \mathrm{O}_{2}$ [8-11]. Catalysts based on niobium oxides were also used in the process of ethanol (EtOH) conversion to 1,3-butadiene (BD) [12,13].

Coordination state of niobium in a carrier matrix significantly influences the activity of niobium-containing sites in a catalyst. Guidotti with co-workers [8] reported that $\mathrm{Nb} / \mathrm{SiO}_{2}$ catalysts, prepared by a co-precipitation method, have higher activity and stability in alkenes epoxidation in the presence of aqueous hydrogen peroxide due to the conservation of coordination state and uniform distribution of $\mathrm{Nb}$ on the carrier surface in contrast to $\mathrm{Nb} / \mathrm{SiO}_{2}$ prepared by deposition. NbBEA zeolites, obtained by direct hydrothermal synthesis, catalyze Meerwein-Ponndorf-Verley (MPV) reduction and etherification processes more effectively than samples prepared by impregnation [14]. The similar effect was observed for Zr-containing systems in $\mathrm{EtOH}$ conversion to $\mathrm{BD}$ [15] i.e. greater specific catalytic activity of ZrBEA in comparison with $\mathrm{Zr} / \mathrm{MCM}-41$ and $\mathrm{ZrO}_{2} / \mathrm{SiO}_{2}$ was caused by higher content of isolated $\mathrm{Zr}(\mathrm{IV}$ ) sites in the ZrBEA catalyst.

We have recently shown [16] that two-step postsynthesis method of tantalum incorporation in BEA zeolite framework as isolated mononuclear $\mathrm{Ta}(\mathrm{V})$ allows preparing highly selective tantalum-silicate catalysts for the conversion of $\mathrm{EtOH}$ and acetaldehyde (AA) mixture into BD. A clear distinction between postsynthesized and hydrothermally synthesized SnBEA zeolites was showed in Baeyer-Villiger and MPV reactions [17,18]. Catalytic activity of dealuminated Sn-containing BEA zeolite is supposed to be associated with the structural difference of Sn-containing active sites, especially with the presence of frustrated Lewis acidbase pairs with outersphere coordination of $\mathrm{SiO}^{-}$. Obviously, incorporation of metals in a 
framework of dealuminated BEA zeolite is a more convenient way to form isolated metal species in the silicate matrix.

This paper is aimed to study the effect of the niobium state present in BEA zeolite matrix on the activity and selectivity of $\mathrm{NbSiBEA}$ catalysts in so-called tandem processes, requiring different types of active sites (redox and/or acid-base). In particular, the $\mathrm{Nb}$-containing catalysts were tested in gas- and liquid-phase processes: (1) EtOH conversion to BD, and (2) direct synthesis of unsymmetrical ethers from aromatic aldehyde and aliphatic alcohol (4methoxybenzaldehyde and 2-butanol).

\section{Experimental}

\subsection{Catalysts preparation}

A tetraethylammonium BEA was placed in a aqueous solution of $13 \mathrm{~mol} \cdot \mathrm{L}^{-1} \mathrm{HNO}_{3}$ and lasted at $353 \mathrm{~K}$ during $4 \mathrm{~h}$ to obtain a dealuminated organic-free BEA, as previously described $[19,20]$. The obtained SiBEA $(\mathrm{Si} / \mathrm{Al}=1300)$ with vacant $\mathrm{T}$-atom sites was recovered by centrifugation, washed with distilled water and dried in air at $353 \mathrm{~K}$ during $24 \mathrm{~h}$.

In order to introduce niobium ions into framework of BEA zeolite, two portion of $2 \mathrm{~g}$ of SiBEA were stirred for $3 \mathrm{~h}$ at $353 \mathrm{~K}$ in $100 \mathrm{~mL}$ of isopropanol (dry) solutions containing $1.5 \times$ $10^{-3}$ and $4.4 \times 10^{-3} \mathrm{~mol} \cdot \mathrm{L}^{-1} \mathrm{Nb}\left(\mathrm{OC}_{2} \mathrm{H}_{5}\right)_{5}$ (Alfa Aesar, $99.999 \%$ ), respectively. Then, two suspensions at $\mathrm{pH}=5.6$ and 2.5 , respectively, were stirred in air at $353 \mathrm{~K}$ for $1 \mathrm{~h}$ to evaporate the solvent. The resulting samples were washed in distilled water (three times), dried (in air at $353 \mathrm{~K}$ for $24 \mathrm{~h}$ ) and calcined (in flowing air at $723 \mathrm{~K}$ for $3 \mathrm{~h}$ ). The obtained samples containing 0.7 and $2.0 \mathrm{wt} \%$ of $\mathrm{Nb}$ were labeled $\mathrm{Nb}{ }_{0.7} \mathrm{SiBEA}$ and $\mathrm{Nb}_{2.0} \mathrm{SiBEA}$, respectively.

\subsection{Catalysts characterization}

The chemical analysis of zeolites was performed with ICP atom emission spectroscopy at the CNRS Centre of Chemical Analysis (Vernaison, France). 
Textural properties of studied samples were determined by low-temperature (77 K) $\mathrm{N}_{2}$ sorption on an Autosorb-1 (Quantachrome, USA). The zeolites, before analysis, were treated under vacuum at $383 \mathrm{~K}$ for $18 \mathrm{~h}$. The specific surface area was calculated from the BET method and the micropore volume was determined using Vt-plot method.

X-ray diffraction (XRD) patterns of the powder samples were recorded using D8 Advance (Bruker AXS GmbH, Germany) diffractometer with monochromatized $\mathrm{Cu}-\mathrm{K} \alpha$ radiation (nickel filter, $\lambda=0.15418 \mathrm{~nm}$ ). The $\mathrm{d}_{302}$ spacing was calculated using equation:

$$
\mathrm{n} \lambda=2 \mathrm{~d} \cdot \sin \theta
$$

where $n$ is an integer ( $n=1), \lambda$ is the wavelength of incident wave, $d$ is the spacing between the planes in the atomic lattice, and $\theta$ is an angle between the incident ray and the scattering planes.

NMR spectra were registered using Avance 400 spectrometer (Bruker, Germany). ${ }^{29} \mathrm{Si}$ MAS NMR spectra were recorded at $79.5 \mathrm{MHz}$ using $7 \mathrm{~mm}$ (external diameter) zirconia rotors, with CP ( ${ }^{1} \mathrm{H}-{ }^{29} \mathrm{Si}$ CP-MAS NMR) and without $\left({ }^{29} \mathrm{Si}\right.$ MAS NMR). Chemical shifts of silicon were measured relative to tetramethylsilane (TMS). ${ }^{29} \mathrm{Si}$ MAS NMR spectra were obtained with rotors spinning speed of $4 \mathrm{kHz}$, excitation pulse duration of $2.5 \mu \mathrm{s}$ and recycle delay of $10 \mathrm{~s}$. Polydimethylsilane (PDMS) was used for setting the Hartmann-Hahn condition. The proton $\pi / 2$ pulse duration, the contact time and recycle delay were $6.8 \mu \mathrm{s}, 5 \mathrm{~ms}$ and $5 \mathrm{~s}$, respectively. ${ }^{1} \mathrm{H}$ MAS NMR spectra were recorded using $4 \mathrm{~mm}$ zirconia rotors with a $90^{\circ}$ pulse duration of $3 \mu \mathrm{s}$ and a recycle delay of $6 \mathrm{~s}$.

Diffuse reflectance (DR) UV-vis spectra were recorded at ambient atmosphere with polytetrafluoroethylene as reference using Cary 5000 spectrometer (Varian, USA) equipped with a double integrator.

Fourier Transform Infrared Spectroscopy (FTIR) spectra were recorded at a spectral resolution of $1 \mathrm{~cm}^{-1}$ on $\mathrm{KBr}$ pellets using a Spectrum One FTIR spectrometer (Perkin Elmer, USA). 
Transmission FTIR spectra of self-supported wafers were recorded using a Vertex 70 spectrometer (Bruker, Germany) accumulating 128 scans at a resolution of $2 \mathrm{~cm}^{-1}$. The wafers were activated by calcination at $723 \mathrm{~K}$ for $2 \mathrm{~h}$ in flowing $2.5 \% \mathrm{O}_{2}$ in $\mathrm{Ar}$ and then outgassed at $573 \mathrm{~K}\left(10^{-3} \mathrm{~Pa}\right)$ for $1 \mathrm{~h}$ before each measurement.

Analysis of acidic properties of the zeolites was performed by adsorption of pyridine and 2,6-di-tert-butylpyridine (DTBP) followed by infrared spectroscopy. Before analysis, the samples were pressed at $\sim 2$ ton $\mathrm{cm}^{-2}$ into thin wafers of ca. $12 \mathrm{mg} \cdot \mathrm{cm}^{-2}$ and placed inside the IR cell. FTIR spectra with pyridine or DTBP were recorded on a Spectrum One FTIR spectrometer (Perkin Elmer, USA) accumulating $48 \mathrm{scans}$ at a spectral resolution of $1 \mathrm{~cm}^{-1}$. The cell was connected to a vacuum-adsorption apparatus allowing a residual pressure below $10^{-3} \mathrm{~Pa}$. The spectra were recorded under ambient conditions after pyridine desorption at 423, 523, 573 and $623 \mathrm{~K}$ and after DTBP desorption at $423 \mathrm{~K}$. Before pyridine or DTBP adsorption, the samples were outguessed $\left(10^{-3} \mathrm{~Pa}\right)$ at $673 \mathrm{~K}$ for $1 \mathrm{~h}$. All measured spectra were recalculated to a “normalized" wafer weight.

\subsection{Catalytic activity measurement}

\subsubsection{Gas-phase process}

Catalytic activity tests were carried out at 1 bar in a fixed-bed flow (quartz) reactor with inner diameter of $4 \mathrm{~mm}$. Samples with grains of $0.25-0.5 \mathrm{~mm}(0.25 \mathrm{~g}$, $)$ were used. Before reaction the samples were treated at $673 \mathrm{~K}$ under flowing argon for $1 \mathrm{~h}$. EtOH or the mixtures of $\mathrm{EtOH} / \mathrm{AA}$ and EtOH/crotonaldehyde were fed into the catalytic reactor (weight hourly space velocity $(\mathrm{WHSV})=0.8 \mathrm{~g}_{\text {reagents }} \cdot g_{\text {cat }}{ }^{-1} \cdot h^{-1}$, with Ar as a carrier gas and a flow rate of $15 \mathrm{~mL} / \mathrm{min}$ ). The reagents and obtained products were analyzed chromatographically (KristalLyuks 4000M, MetaChrom, Russia). To identify $\mathrm{CO}, \mathrm{CO}_{2}$ a thermal conductivity detector and a packed column $\left(10 \% \mathrm{NiSO}_{4}\right.$ on coal, $\left.3 \mathrm{~m} \times 3 \mathrm{~mm}\right)$ were used, for organic compounds - a flame ionization detector and a capillary column (HP-FFAP, $50 \mathrm{~m} \times 0.32 \mathrm{~mm}$ ). 
Total conversion (TC) of the reagents (EtOH, EtOH/AA and EtOH/crotonaldehyde mixtures), selectivity to products $\left(S_{j}\right)$ and BD yield $\left(Y_{B D}\right)$ were calculated by the following formulas:

$$
\begin{aligned}
& T C=\frac{\sum n_{i}^{0}-\sum n_{i}}{\sum n_{i}^{0}} \cdot 100, \% \\
& S_{j}=\frac{n_{j}}{\sum n_{i}^{0}-\sum n_{i}} \cdot 100, \% \\
& Y_{B D}=T C \cdot S_{B D} / 100, \%
\end{aligned}
$$

where $n_{i}^{0}$ is the initial amount of C moles of the reagents, $n_{i}$ and $n_{j}$ are the amount of $\mathrm{C}$ moles of the unreacted reagents $i$ and product $j$ in the stream of the reaction products.

Turnover frequency (TOF) was obtained by dividing the number of moles of reacted reagent(s) or obtained product(s) with number of moles of $\mathrm{Nb}$ per one hour.

\subsubsection{Liquid-phase process}

Zeolite catalyst $(100 \mathrm{mg})$ after activation $(773 \mathrm{~K}, 2 \mathrm{~h})$ was added to the stock solution of 4-methoxybenzaldehyde (1) $(1.25 \mathrm{mmol})$ in 2-butanol $(4 \mathrm{~g})$. The reaction mixture was heated to $353 \mathrm{~K}$ with vigorous stirring. At various time intervals, aliquots were taken from the reaction mixture and analyzed after separation of the catalyst by centrifugation. The progress of the reaction was analyzed by a gas chromatograph (KristalLyuks 4000M, MetaChrom, Russia) equipped with an FID detector and a capillary column (HP-FFAP) using mesitylene as an internal standard for quantification. The reactants and products were identified on the basis of coincidence of retention times with those of extra pure standards.

Catalytic activity was characterized by the conversion $(C)$ of aldehyde $\mathbf{1}$ and selectivities of products $\left(S_{k}\right)$.

$$
\begin{aligned}
& C=\frac{n_{\text {Ald.1 }}^{0}-n_{\text {Ald } .1}}{n_{\text {Ald.1 }}^{0}} \cdot 100, \% \\
& S_{k}=\frac{n_{k}}{n_{\text {Ald.1 }}^{0}-n_{\text {Ald } .1}} \cdot 100, \%
\end{aligned}
$$


where $n_{\text {Ald.1 }}^{0}$ is the initial amount of $\mathrm{C}$ moles of aldehyde $\mathbf{1}, n_{\text {Ald.1 }}$ and $n_{k}$ are the amount of $\mathrm{C}$ moles of aldehyde $\mathbf{1}$ and product $k$ in the reaction products.

Turnover number $(T O N)$ was calculated as number of moles of reacted aldehyde $\mathbf{1}$ (after $10 \mathrm{~h}$ ) divided by number of moles of $\mathrm{Nb}$.

For the etherification reaction of 4-methoxybenzyl alcohol (2) with 2-butanol, the stock solution, containing alcohol $2(2.5 \mathrm{mmol})$ in 2-butanol $(4 \mathrm{~g})$ was used. The progress of the reaction was analyzed as described hereinabove.

\section{Results and discussion}

\subsection{Prove for the incorporation of $\mathrm{Nb}$ in $\mathrm{BEA}$ zeolite}

The samples prepared by postsynthesis method, hereafter referred to as $\mathrm{Nb}_{0.7} \mathrm{SiBEA}$ and $\mathrm{Nb}_{2.0} \mathrm{SiBEA}$, are white and contain 0.7 and $2.0 \mathrm{Nb}$ wt $\%$.

The textural properties of HAlBEA, SiBEA, $\mathrm{Nb}_{0.7} \mathrm{SiBEA}$ and $\mathrm{Nb}_{2.0} \mathrm{SiBEA}$ were studied by means of low-temperature nitrogen sorption. Fig. 1 exhibits nitrogen sorption isotherms of all samples. All of them are type I according to IUPAC. The values of BET specific surface area and micropore volumes of HAlBEA, $\mathrm{SiBEA}, \mathrm{Nb}_{0.7} \mathrm{SiBEA}$ and $\mathrm{Nb}_{2.0} \mathrm{SiBEA}$ were in the ranges of 460-491 $\mathrm{m}^{2} \mathrm{~g}^{-1}$ and $0.19-0.21 \mathrm{~cm}^{3} \mathrm{~g}^{-1}$, respectively (Table 1) characteristics of BEA zeolite.

XRD patterns of SiBEA, $\mathrm{Nb}_{0.7} \mathrm{SiBEA}$ and $\mathrm{Nb}_{2.0} \mathrm{SiBEA}$ are typical for BEA zeolite (Fig. 2). Dealumination of BEA zeolite with $\mathrm{HNO}_{3}$ and following incorporation of niobium ions in the framework of $\mathrm{SiBEA}$ zeolite as mononuclear $\mathrm{Nb}(\mathrm{V})$ does not affect structure crystallinity, in line with earlier reports [21,22]. The shift of diffraction peak about $22.6^{\circ}$ as a result of removal of $\mathrm{Al}$ atoms from zeolite framework and incorporation of metal ions is used as prove for zeolite matrix contraction/expansion [19,20,23]. The significant decrease of the $\mathrm{d}_{302}$ spacing from $3.943 \AA\left(\mathrm{HAlBEA} ; 2 \theta=22.55^{\circ}\right)$ to $3.920 \AA\left(\operatorname{SiBEA} ; 2 \theta=22.67^{\circ}\right)$ upon dealumination suggest contraction of the BEA matrix. A strong increase of $\mathrm{d}_{302}$ spacing from $3.920 \AA$ (SiBEA; $2 \theta=$ $\left.22.67^{\circ}\right)$ to $3.957\left(\mathrm{Nb}_{0.7} \operatorname{SiBEA} ; 2 \theta=22.44^{\circ}\right)$ and $3.946 \AA\left(\mathrm{Nb}_{2.0} \operatorname{SiBEA} ; 2 \theta=22.50^{\circ}\right)$ observed 
after incorporation of $\mathrm{Nb}$ into SiBEA points out its expansion due to longer $\mathrm{Nb}-\mathrm{O}$ bond length (1.89 for tetracoordinated $\mathrm{Nb}(\mathrm{V})$ in BEA zeolite [14]) as compared with $\mathrm{Si}-\mathrm{O}$ (typically 1.60 $1.65 \AA$ in zeolites [24]). The lower increase of $\mathrm{d}_{302}$ value appeared for $\mathrm{Nb}_{2.0} \mathrm{SiBEA}$ than for $\mathrm{Nb}_{0.7} \mathrm{SiBEA}$ and $\mathrm{Nb}_{1.0} \mathrm{SiBEA}, \mathrm{Nb}_{1.5} \mathrm{SiBEA}, \mathrm{Nb}_{1.6} \mathrm{SiBEA}[21,22]$ with only framework mononuclear $\mathrm{Nb}(\mathrm{V})$ suggests that for former zeolite only a part of niobium was incorporated in the zeolite framework.

The ${ }^{29} \mathrm{Si}$ MAS NMR spectrum of SiBEA (Fig. 3) contains signals at $-102.3,-111.0$ and $-114.3 \mathrm{ppm}$. The peaks at -111.0 and $-114.3 \mathrm{ppm}$ are caused by framework $\mathrm{Si}$ atoms in $\mathrm{Si}(\mathrm{OSi})_{4}$ environment, located at different crystallographic sites [25]. The peak at $-102.3 \mathrm{ppm}$ is attributed to $\mathrm{Si}$ atoms in $\mathrm{Si}(\mathrm{OH})(\mathrm{OSi})_{3}$ environment. It is confirmed by a significant increase of intensity of the peak at $-102.3 \mathrm{ppm}$ when ${ }^{1} \mathrm{H}-{ }^{29} \mathrm{Si} \mathrm{CP}-\mathrm{MAS}$ NMR technique is applied (Fig. 4), since the signal of ${ }^{29} \mathrm{Si}$ nuclei close to protons is preferentially enhanced.

After incorporation of niobium ions in SiBEA, the intensity of the peak at about $-102 \mathrm{ppm}$ is noticeably decreased for $\mathrm{Nb}_{0.7} \mathrm{SiBEA}$ and $\mathrm{Nb}_{2.0} \mathrm{SiBEA}$ (Fig. 3). It confirms the reaction between niobium ethoxide $\left(\mathrm{Nb}\left(\mathrm{OC}_{2} \mathrm{H}_{5}\right)_{5}\right)$ precursor and silanol groups of vacant $\mathrm{T}$ atoms. However, the absence of further decrease of the peak at $-102.2 \mathrm{ppm}$ after introduction of more amount of niobium $\left(\mathrm{Nb}_{2.0} \mathrm{SiBEA}\right)$ suggests that major part of niobium is not incorporated in framework of $\mathrm{Nb}_{2.0} \mathrm{SiBEA}$. It seems that these niobium ions are introduced in extraframework position of BEA zeolite as polynuclear $\mathrm{Nb}(\mathrm{V})$. In contrast, for $\mathrm{Nb}_{0.7} \mathrm{SiBEA}$ the peak at -102.4 ppm prove that almost all niobium is incorporated as isolated mononuclear $\mathrm{Nb}(\mathrm{V})$.

The change of the $\mathrm{Si}(\mathrm{OSi})_{4}$ environment takes place upon incorporation of $\mathrm{Nb}$ ions in SiBEA as deduced from the appearance of the well distinguished ${ }^{29} \mathrm{Si}$ MAS NMR peaks at -114.0 and $-114.1 \mathrm{ppm}$ for $\mathrm{Nb}_{0.7} \mathrm{SiBEA}$ and $\mathrm{Nb}_{2.0} \mathrm{SiBEA}$, respectively (Fig. 3). In contrast, for SiBEA only shoulder is present at around -114.3. It suggests that the incorporation of $\mathrm{Nb}$ in SiBEA modify the silicon environment. 
Concerning ${ }^{1} \mathrm{H}$ MAS NMR spectra (Fig. 5), two main peaks are observed at 1.4 and $5.4 \mathrm{ppm}$ for $\mathrm{SiBEA}$, indicating the presence of protons of isolated (and/or terminal) $\mathrm{SiO}-\mathrm{H}$ and hydrogen bonded silanol groups at vacant T-atom sites, respectively [26,27]. A small peak at $3.3 \mathrm{ppm}$ is due to protons of H-bonded silanol groups present in a second kind of crystallographic sites. This shift is comparable with that observed at $3.20 \mathrm{ppm}$ for H-bonded silanol groups in silica and silicalite $[28,29]$. The disappearance of the peak at $5.4 \mathrm{ppm}$ after incorporation of $\mathrm{Nb}$ in SiBEA (Fig. 5) proves the reaction of niobium ethoxide precursor with both H-bonded silanol groups. The ${ }^{1} \mathrm{H}$ MAS NMR spectra of $\mathrm{Nb}_{0.7} \mathrm{SiBEA}$ and $\mathrm{Nb}_{2.0} \mathrm{SiBEA}$ allow distinguishing the peak with high intensity at around 3.8-4.1 ppm and two other peaks with low intensity at 2.0 and $1.2 \mathrm{ppm}$. The peaks with low intensity are probably due to protons of isolated and terminal silanol, respectively [30], still present in $\mathrm{Nb}_{0.7} \mathrm{SiBEA}$ and $\mathrm{Nb}_{2.0} \mathrm{SiBEA}$ after incorporation of $\mathrm{Nb}$ into the vacant $\mathrm{T}$-atom sites of SiBEA.

The DR UV-vis spectrum of $\mathrm{Nb}_{0.7} \mathrm{SiBEA}$ demonstrates the presence of two absorption bands at 220 and $234 \mathrm{~nm}$ (Fig. 6) corresponding to different mononuclear $\mathrm{Nb}(\mathrm{V})$ present in the framework of BEA zeolite and are assigned to oxygen-tetrahedral $\mathrm{Nb}(\mathrm{V})$ ligand-to-metal charge transfer transitions $[21,22,31,32]$. The absence of bands at around $330-450 \mathrm{~nm}$ assigned to niobia-like phases $[31,33]$ indicates that these form of $\mathrm{Nb}$ species are not present in $\mathrm{Nb}_{0.7} \mathrm{SiBEA}$.

In the DR UV-vis spectrum of $\mathrm{Nb}_{2.0} \mathrm{SiBEA}$ the three bands at 228, 248 and $370 \mathrm{~nm}$ (Fig. 6) appear corresponding to $\mathrm{Nb}(\mathrm{V})$ framework mononuclear $\mathrm{Nb}(\mathrm{V})$ (band at $228 \mathrm{~nm}$ ), extraframework polynuclear $\mathrm{Nb}(\mathrm{V})(248 \mathrm{~nm})$ and niobium oxides $(370 \mathrm{~nm})$ [6]. Lower intensity of the band at $228 \mathrm{~nm}$ on $\mathrm{Nb}_{2.0} \mathrm{SiBEA}$ than the bands at 220 and $234 \mathrm{~nm}$ on $\mathrm{Nb} 0.7 \mathrm{SiBEA}$ spectrum reveals lower content of mononuclear $\mathrm{Nb}(\mathrm{V})$ in $\mathrm{Nb}_{2.0} \mathrm{SiBEA}$ than in $\mathrm{Nb}{ }_{0.7} \mathrm{SiBEA}$. The absence of (d-d) transitions for both $\mathrm{Nb}_{2.0} \mathrm{SiBEA}$ and $\mathrm{Nb}_{0.7} \mathrm{SiBEA}$ in the range of $600-800 \mathrm{~nm}$ suggests that $\mathrm{Nb}(\mathrm{IV})$ species are not present.

After treatment of TEABEA zeolite with acid nitric the bands attributed to the $\mathrm{OH}$ stretching modes of AlO-H groups (3782 and $\left.3665 \mathrm{~cm}^{-1}\right)$ and $\mathrm{Al}-\mathrm{O}(\mathrm{H})-\mathrm{Si}$ groups $\left(3608 \mathrm{~cm}^{-1}\right)$ 
$[19,34]$ are not observed in the spectrum of SiBEA (Fig. 7), proving the full removal of aluminium. The occurring of narrow bands at 3736 and $3705 \mathrm{~cm}^{-1}$ and a broad band at $3515 \mathrm{~cm}^{-1}$ related to isolated $\mathrm{SiO}-\mathrm{H}$ groups and $\mathrm{H}$-bonded $\mathrm{SiO}-\mathrm{H}$ groups, respectively, proves the formation of vacant T-atom sites in SiBEA, as reported previously [34]. The incorporation of niobium in the zeolite induces a reduction of intensity of all these bands, suggesting the reaction of $\mathrm{SiO}-\mathrm{H}$ groups, with the niobium precursor. For $\mathrm{Nb}_{0.7} \mathrm{SiBEA}$ and $\mathrm{Nb}_{2.0} \mathrm{SiBEA}$ a band at $3745 \mathrm{~cm}^{-1}$ appears in the spectra, related to $\mathrm{Nb}(\mathrm{V}) \mathrm{O}-\mathrm{H}$.

The niobium incorporation in SiBEA modifies the Si environment as shown by changes of the stretching vibration of $\mathrm{Si}-\mathrm{O}[22]$. The band at $955 \mathrm{~cm}^{-1}$ observed in FTIR spectrum of SiBEA reveals the presence of Si-O group in vacant T-atom sites, as reported previously [20]. The incorporation of niobium into these sites modifies the $\mathrm{Si}-\mathrm{O}$ stretching vibration that appears at higher wavenumber $\left(960 \mathrm{~cm}^{-1}\right)$ on both $\mathrm{Nb}_{0.7} \mathrm{SiBEA}$ and $\mathrm{Nb}_{2.0}$ SiBEA FTIR spectra than on SiBEA spectrum $\left(955 \mathrm{~cm}^{-1}\right)$ (Fig. 8). The modifications of the band at $1223-1238 \mathrm{~cm}^{-1}$ characteristic of BEA zeolite and associated with the specific arrangement of tetrahedral Si(IV) sites are due to the increase of the unit cell parameter upon incorporation of niobium into the framework (XRD results, Fig. 2).

FTIR spectra of pyridine adsorbed on $\mathrm{Nb}_{0.7} \mathrm{SiBEA}$ and $\mathrm{Nb}_{2.0} \mathrm{SiBEA}$ are seen in Fig. 8 . The bands at 1445,1578 and $1596 \mathrm{~cm}^{-1}$ correspond to weakly bonded pyridine [35], as proved by their disappearance after desorption of pyridine at $523 \mathrm{~K}$. In contrast, the bands appeared at 1450, 1600 and $1611 \mathrm{~cm}^{-1}$ correspond to pyridine coordinatively bonded to Lewis acidic sites (LAS) $\left(\mathrm{Nb}(\mathrm{V})\right.$ species) [36]). The intensity of absorption bands at 1611 and $1600 \mathrm{~cm}^{-1}$ for $\mathrm{Nb}_{2.0} \mathrm{SiBEA}$ is comparable to $\mathrm{Nb}$. $_{7} \mathrm{SiBEA}$, which contains almost three times less niobium. It suggests that major amount of LAS are formed by niobium introduced in the framework of SiBEA as mononuclear $\mathrm{Nb}(\mathrm{V})$. The intensity of these bands for SiBEA is much lower than for $\mathrm{Nb}_{0.7} \mathrm{SiBEA}$ and $\mathrm{Nb}_{2.0} \mathrm{SiBEA}$, as reported earlier [21,37] and proves that they are related to pyridine adsorbed on niobium. 
The Lewis acidic sites (LAS) concentrations has been calculated from intensity of the band at $1450 \mathrm{~cm}^{-1}$ corresponding to pyridine coordinately bonded to Lewis acidic sites observed in FTIR spectra after adsorption of pyridine at room temperature and then desorption at different temperatures $423,523,573$ and $623 \mathrm{~K}$. The results for $\mathrm{Nb}_{0.7} \mathrm{SiBEA}$ and $\mathrm{Nb}_{2.0} \mathrm{SiBEA}$ are shown in Table 2. The similar concentration values obtained for $\mathrm{Nb}_{0.7} \mathrm{SiBEA}$ and $\mathrm{Nb}_{2.0} \mathrm{SiBEA}$ after desorption of pyridine at different temperatures indicate that LAS are mainly formed upon incorporation of niobium in the framework of SiBEA zeolite.

Brønsted acidic sites (BAS) were not identified in both $\mathrm{Nb}_{0.7} \mathrm{SiBEA}$ and $\mathrm{Nb}_{2.0} \mathrm{SiBEA}$ samples (the band of pyridinium cations at $1550 \mathrm{~cm}^{-1}$ on FTIR spectra is absent, Fig. 9 A and B).

DTBP as stronger base than pyridine has been used to establish presence of weak BAS preferentially on external surface. FTIR spectra of DTBP adsorbed on $\mathrm{Nb}_{0.7} \mathrm{SiBEA}$ and $\mathrm{Nb}_{2.0} \mathrm{SiBEA}$ are presented in Fig. 10. According to previous works [38,39], the bands at 1615 and $1532 \mathrm{~cm}^{-1}$ are assigned to the protonated DTBP adsorbed on BAS. The intensity of these bands is slightly higher for $\mathrm{Nb}_{0.7} \mathrm{SiBEA}$ than for $\mathrm{Nb}_{2.0} \mathrm{SiBEA}$, indicating the higher amount of weak BAS in former than in latter zeolite.

Thus, incorporation of niobium into the framework of $\mathrm{SiBEA}$ as mononuclear $\mathrm{Nb}(\mathrm{V})$ is proved by XRD, DR UV-vis, NMR and FTIR. DR UV-vis study shows that two types of framework mononuclear $\mathrm{Nb}(\mathrm{V})$ are present in $\mathrm{Nb}_{0.7} \mathrm{SiBEA}$, while $\mathrm{Nb}_{2.0} \mathrm{SiBEA}$ contains both framework mononuclear $\mathrm{Nb}(\mathrm{V})$ and extra-framework polynuclear $\mathrm{Nb}(\mathrm{V})$. The presence of Lewis acidic sites, formed by framework mononuclear $\mathrm{Nb}(\mathrm{V})$, and weak Brønsted acidic sites was identified by FTIR using pyridine and DTBP as probe molecules.

\subsection{Catalytic properties of NbSiBEA zeolites in tandem processes}

\subsubsection{Gas-phase process: conversion of EtOH into BD}

Scheme 1 shows consecutive steps of gas-phase process of EtOH conversion to BD, such as AA formation from EtOH, aldol condensation of AA to acetaldol, dehydration of acetaldol to 
crotonaldehyde, Meerwein-Ponndorf-Verley reduction of crotonaldehyde with EtOH to crotyl alcohol and AA, and dehydration of crotyl alcohol to BD [40,41]. Scheme 1 also shows the main side process, which is EtOH dehydration to diethyl ether (DEE) and then to ethylene. Consequently, bifunctional catalyst capable of catalyzing both hydrogen transfer (redox process), and aldol condensation and dehydration, is necessary for selective BD synthesis from ethanol $[42-45]$.

EtOH conversion. The catalytic performance of NbSiBEA zeolites has been shown in Table 3. The main products of EtOH conversion are BD, AA, ethylene and DEE. Small quantity of crotonaldehyde was identified. In the presence of $\mathrm{Nb}_{0.7 \mathrm{SiBEA}}$ almost two times higher yield of $\mathrm{BD}$ is achieved than on $\mathrm{Nb}_{2.0} \mathrm{SiBEA}$ due to greater EtOH conversion and selectivity to BD. Another difference between two catalysts could be seen from the selectivities toward formation of the products of EtOH dehydrogenation (AA) and dehydration (ethylene + DEE). Higher residual amount of $\mathrm{AA}$ observed for $\mathrm{Nb}_{2.0} \mathrm{SiBEA}$ catalyst could indicate the lower quantity of sites of aldol condensation on its surface. High selectivity to ethylene and DEE for $\mathrm{Nb}_{0.7} \mathrm{SiBEA}$ testify to greater quantity of acidic sites, on which dehydration reaction occurs. It should be pointed out that only trace amount of DEE was observed in the presence of $\mathrm{Nb}$-free $\mathrm{SiBEA}$ zeolite, which may be formed during ethanol etherification on weak Lewis acidic sites [36].

TOF values for NbSiBEA catalysts in the ethanol conversion have been shown in Table 4. Turnover frequency for $\mathrm{Nb}_{0.7} \mathrm{SiBEA}$ is several times higher than for $\mathrm{Nb}_{2.0} \mathrm{SiBEA}$. Thus, it seems that framework mononuclear $\mathrm{Nb}(\mathrm{V})$ efficiently catalyze the processes, which occur on acidic sites (aldol condensation of $\mathrm{AA}, \mathrm{EtOH}$ dehydration to ethylene and DEE). In addition, TOF of the redox reaction of dehydrogenation for $\mathrm{Nb}_{0.7 \mathrm{SiBEA}}$ is almost four times higher than for $\mathrm{Nb}_{2.0} \mathrm{SiBEA}$, which is consistent with the results obtained for alkenes epoxidation in the presence of aqueous hydrogen peroxide [8].

EtOH/AA mixture conversion. The activity and selectivity of NbSiBEA catalysts were evaluated in the conversion of ethanol and acetaldehyde mixture. Addition of AA (an 
intermediate, which takes part in the step of aldol condensation) to EtOH will allow estimating the effect of niobium location in the zeolite matrix on the activity of a catalyst in this step.

In the presence of $\mathrm{Nb}_{0.7 \mathrm{SiBEA}}$ total conversion of EtOH/AA mixture, BD yield (Table 3) and TOF (Table 4) are higher than for $\mathrm{Nb}_{2.0} \mathrm{SiBEA}$. However, the selectivity to $\mathrm{BD}$ is significantly higher for the $\mathrm{Nb}_{2.0} \mathrm{SiBEA}$ catalyst at $598 \mathrm{~K}$ (70.6 \%) than for $\mathrm{Nb}_{0.7} \mathrm{SiBEA}(54.8 \%)$ under the same conditions. The selectivity of BD formation at $623 \mathrm{~K}$ for both catalysts is close. Decrease in selectivity to $\mathrm{BD}$ in the case of $\mathrm{Nb}_{2.0} \mathrm{SiBEA}$ at higher temperature is attributed to the increase in a rate of thermodynamically more favorable endothermic reaction of EtOH dehydration to ethylene. Change of selectivity to ethylene for $\mathrm{Nb}_{2.0 \mathrm{SiBEA}}$ catalyst from $11.9 \%$ to $29.5 \%$ with increasing of the reaction temperature from 598 to $623 \mathrm{~K}$ and selectivity preservation for $\mathrm{Nb}_{0.7 \mathrm{SiBEA}}$ may indicate that dehydration process could occur on LAS, formed by extra-framework $\mathrm{Nb}(\mathrm{V})$ species.

Significantly higher TOF values for the dehydration products (ethylene + DEE) is observed on the catalyst, containing only framework mononuclear niobium $\left(\mathrm{Nb}_{0.7} \mathrm{SiBEA}\right)$, compared with the sample, containing extra-framework octahedral $\mathrm{Nb}(\mathrm{V})$ ( $\mathrm{Nb}_{2.0} \mathrm{SiBEA}$ ) (Table 4). Thus, it is further evidence of higher activity of framework mononuclear $\mathrm{Nb}(\mathrm{V})$, characterized by stronger acidic character than extra-framework octahedral niobium.

It should be noted that higher amount of crotonaldehyde is present in the products of conversion of EtOH/AA mixture on $\mathrm{Nb}_{2.0} \mathrm{SiBEA}$ (Table 4). The substantial difference in the selectivity to crotonaldehyde, probably, indicates that MPV reduction of crotonaldehyde with $\mathrm{EtOH}$, along with aldol condensation, become key step under the used experimental conditions. Since $\mathrm{Nb}_{2.0 \mathrm{SiBEA}}$ contains less amount of isolated framework mononuclear $\mathrm{Nb}(\mathrm{V})$ than $\mathrm{Nb}_{0.7 \mathrm{SiBEA}}$, it can be assumed that MPV reduction of crotonaldehyde proceeds with higher rate in the presence of such niobium species than $\mathrm{Nb}_{2} \mathrm{O}_{5}$ nanoparticles. A similar conclusion was made for Zr(IV)-based systems [44]. 
EtOH/crotonaldehyde mixture conversion. Analogous method of intermediate addition was applied in order to estimate the effect of niobium location in the zeolite matrix on the activity of a catalyst in the step of crotonaldehyde MPV reduction to crotyl alcohol. Catalytic performance of the NbSiBEA catalysts in the conversion of EtOH/crotonaldehyde mixture has been shown in Table 5 .

The total conversion of EtOH/crotonaldehyde mixture is higher for $\mathrm{Nb}_{0.7} \mathrm{SiBEA}$ than $\mathrm{Nb}_{2.0} \mathrm{SiBEA}$. The residual content of crotonaldehyde in the products for both catalysts is low and differs slightly, however, amount of BD as well as ethylene (Table 6) and TOF values (Table 4) are higher for $\mathrm{Nb}_{0.7} \mathrm{SiBEA}$ than for $\mathrm{Nb}_{2.0} \mathrm{SiBEA}$. Higher $\mathrm{TOF}$ of $\mathrm{BD}$ formation than crotonaldehyde reaction, especially for $\mathrm{Nb}_{0.7} \mathrm{SiBEA}$ catalyst, is a result of conversion of AA, formed in MPV reduction of crotonaldehyde. Thus, the sample containing higher amount of framework mononuclear $\mathrm{Nb}(\mathrm{V})$ is more active in the processes, which occur on the surface acidic sites. These results confirm the assumption about the different activity of framework and extra-framework $\mathrm{Nb}(\mathrm{V})$ in MPV reduction of crotonaldehyde with EtOH.

\subsubsection{Liquid-phase process: synthesis of unsymmetrical ethers}

NbSiBEA zeolites with different location of niobium were tested in the liquid-phase tandem process (Scheme 2), including MPV reduction of aldehyde 1 with 2-butanol to 4methoxybenzyl alcohol (2), followed by its etherification with 2-butanol to 4-methoxybenzyl 1methylpropyl ether (3). As well as in the case of ethanol conversion into $\mathrm{BD}$, the catalyst of the process should be bifunctional.

Results of evaluation of catalytic properties of NbSiBEA zeolites in the liquid-phase tandem process are shown on Fig. 11 and Table 6. Higher conversion of aldehyde 1 is observed on the catalyst with greater amount of niobium $\left(\mathrm{Nb}_{2.0} \mathrm{SiBEA}\right)$. However, in the presence of the catalyst, containing only framework $\mathrm{Nb}(\mathrm{V})$ species $\left(\mathrm{Nb}_{0.7} \mathrm{SiBEA}\right)$, aldehyde $\mathbf{1}$ is completely converted into ether 3 , while on $\mathrm{Nb}_{2.0} \mathrm{SiBEA}$, containing framework and extra-framework 
niobium species, $67 \%$ selectivity to ether 3 is achieved (Table 7 ). $\mathrm{Nb}_{2.0}$ SiBEA is more active in MPV reduction than etherification process as evidenced by higher conversion of aldehyde $\mathbf{1}$ and incomplete further etherification of alcohol 2.

Different activity of framework and extra-framework $\mathrm{Nb}(\mathrm{V})$ in the etherification was confirmed by the results of the investigation of the reaction of alcohol 2 with 2-butanol in the presence of $\mathrm{Nb}_{0.7} \mathrm{SiBEA}$ and $\mathrm{Nb}_{2.0} \mathrm{SiBEA}$ (Table 8). In the presence of $\mathrm{Nb}_{0.7} \mathrm{SiBEA} 93 \%$ conversion of alcohol 2 is achieved after $2 \mathrm{~h}$, while for $\mathrm{Nb}_{2.0} \mathrm{SiBEA}$ only $37 \%$ is observed after $10 \mathrm{~h}$ of the reaction. Moreover, calculated value of TON for $\mathrm{Nb}{ }_{0.7} \mathrm{SiBEA}$ is significantly higher compared to $\mathrm{Nb}_{2.0} \mathrm{SiBEA}$. So, we may conclude that specific activity of framework mononuclear $\mathrm{Nb}(\mathrm{V})$ is superior than extra-framework octahedral $\mathrm{Nb}(\mathrm{V})$.

NbSiBEA catalysts are more active in the etherification and tandem processes in comparison with the zeolites prepared by impregnation of pure silica BEA with ethanolic solutions of $\mathrm{Nb}(\mathrm{V})$ ethoxides [14]. Therefore, prepared by two-step postsynthesis method Nbcontaining SiBEA zeolite catalysts with framework mononuclear $\mathrm{Nb}(\mathrm{V})$ can be alternative materials to hydrothermally synthesized metal-containing zeolites used as catalysts of liquidphase tandem processes.

\section{Conclusions}

$\mathrm{Nb}_{0.7} \mathrm{SiBEA}$ and $\mathrm{Nb}_{2.0} \mathrm{SiBEA}$ zeolites contain framework mononuclear $\mathrm{Nb}(\mathrm{V})$ and mixture of framework mononuclear and extra-framework polynuclear $\mathrm{Nb}(\mathrm{V})$, respectively, as evidenced by XRD, NMR, DR UV-vis and FTIR.

The state of niobium in zeolite matrix determines acidic properties and, thus, activity of NbSiBEA catalysts in tandem processes, as was shown for gas-phase and liquid-phase processes.

$\mathrm{Nb}_{0.7} \mathrm{SiBEA}$ catalyst is more active than $\mathrm{Nb}_{2.0} \mathrm{SiBEA}$ in the conversion of ethanol and ethanol/acetaldehyde mixture into 1,3-butadiene, MPV reduction of crotonaldehyde with ethanol and etherification of 4-methoxybenzyl alcohol with 2-butanol. 
The higher specific catalytic activity (turnover number/frequency) of Nb0.7SiBEA than $\mathrm{Nb}_{2.0} \mathrm{SiBEA}$ has been revealed for the above mentioned processes.

Thus, two-step postsynthesis preparation procedure allows designing bifunctional NbSiBEA catalysts with redox and acid-base properties required for the occurrence of tandem processes.

\section{Acknowledgements}

Special thanks to Malgorzata Ruggiero (Jerzy Haber Institute of Catalysis and Surface Chemistry

PAS in Krakow, Poland) for BET measurements on HAlBEA, SiBEA, Nb0.7SiBEA and $\mathrm{Nb}_{2.0}$ SiBEA. 


\section{References}

[1] B. Henrique Arpini, A. de Andrade Bartolomeu, C. Kleber Z. Andrade, L. Carlos da Silva-Filho, V. Lacerda, Curr. Org. Synth. 12 (2015) 570.

[2] P. Carniti, A. Gervasini, M. Marzo, Catal. Today 152 (2010) 42.

[3] E.L.S. Ngee, Y. Gao, X. Chen, T.M. Lee, Z. Hu, D. Zhao, Y. Ning, Ind. Eng. Chem. Res. $53(2014) 14225$.

[4] Z. Xue, Y. Zhang, G. Li, J. Wang, W. Zhao, T. Mu, Catal. Sci. Technol. 6 (2016) 1070.

[5] K. Subramaniyan, P. Arumugam, J. Porous Mater. 23 (2016) 639.

[6] X. Gao, I.E. Wachs, M.S. Wong, J.Y. Ying, J. Catal. 203 (2001) 18.

[7] C. García-Sancho, J.A. Cecilia, A. Moreno-Ruiz, J.M. Mérida-Robles, J. SantamaríaGonzález, R. Moreno-Tost, P. Maireles-Torres, Appl. Catal. B Environ. 179 (2015) 139.

[8] C. Tiozzo, C. Palumbo, R. Psaro, C. Bisio, F. Carniato, A. Gervasini, P. Carniti, M. Guidotti, Inorganica Chim. Acta 431 (2015) 190.

[9] A. Gallo, C. Tiozzo, R. Psaro, F. Carniato, M. Guidotti, J. Catal. 298 (2013) 77.

[10] A. Feliczak-Guzik, A. Wawrzyńczak, I. Nowak, Microporous Mesoporous Mater. 202 (2015) 80 .

[11] O.A. Kholdeeva, Catal. Sci. Technol. 7 (2014) 1869.

[12] V. V. Ordomskiy, V.L. Sushkevich, I.I. Ivanova, One-Step Method for Butadiene Production, US 8921635 B2, 2014.

[13] W.J. Toussant, J.T. Dunn, D.R. Jackson, Ind. Eng. Chem. 39 (1947) 120.

[14] A. Corma, F.X. Llabrés I Xamena, C. Prestipino, M. Renz, S. Valencia, J. Phys. Chem. C 113 (2009) 11306.

[15] V.L. Sushkevich, D. Palagin, I.I. Ivanova, ACS Catal. 5 (2015) 4833. 
[16] P.I. Kyriienko, O. V. Larina, S.O. Soloviev, S.M. Orlyk, S. Dzwigaj, Catal. Commun. 77 (2016) 123.

[17] J. Dijkmans, M. Dusselier, W. Janssens, M. Trekels, A. Vantomme, E. Breynaert, C.E.A. Kirschhock, B.F. Sels, ACS Catal. 6 (2015) 31.

[18] J. Dijkmans, J. Demol, K. Houthoofd, S. Huang, Y. Pontikes, B. Sels, J. Catal. 330 (2015) 545 .

[19] S. Dzwigaj, M.J. Peltre, P. Massiani, A. Davidson, M. Che, T. Sen, S. Sivasanker, Chem. Commun. (1998) 87.

[20] S. Dzwigaj, P. Massiani, A. Davidson, M. Che, J. Mol. Catal. A Chem. 155 (2000) 169.

[21] F. Tielens, T. Shishido, S. Dzwigaj, J. Phys. Chem. C 114 (2010) 3140.

[22] S. Dzwigaj, Y. Millot, C. Méthivier, M. Che, Microporous Mesoporous Mater. 130 (2010) 162.

[23] M.A. Camblor, A. Corma, J. Pérez-Pariente, Zeolites 13 (1993) 82.

[24] T. Blasco, M.A. Camblor, A. Corma, P. Esteve, J.M. Guil, A. Mart1, S. Valencia, A. Martinez, J.A. Perdigon-Melon, J. Phys. Chem. B 102 (1998) 75.

[25] C.A. Fyfe, H. Strobl, G.T. Kokotailo, C.T. Pasztor, G.E. Barlow, S. Bradley, Zeolites 8 (1988) 132.

[26] G.L. Woolery, L.B. Alemany, R.M. Dessau, A.W. Chester, Zeolites 6 (1986) 14.

[27] L.W. Beck, J.F. Haw, J. Phys. Chem 99 (1995) 1076.

[28] C. Bronnimann, R. Zeigler, G. Maciel, J. Am. Chem. Soc. 110 (1988) 2023.

[29] A. Maciel, G.E.; Ellis, P.D. in: Bell, A.T.; Pines, NMR Techniques in Catalysis, 1994.

[30] M.A. Aramendia, Y. Avil, V. Borau, C. Jim, J.N.L. Marinas, A. Moreno, J.I.L. Ruiz, React. Kinet. Catal. Lett. 65 (1998) 207. 
[31] M. Hartmann, A.M. Prakash, L. Kevan, Catal. Today 78 (2003) 467.

[32] A.M. Prakash, L. Kevan, J. Am. Chem. Soc. 120 (1998) 13148.

[33] M. Trejda, A. Tuel, J. Kujawa, B. Kilos, M. Ziolek, Microporous Mesoporous Mater. 110 (2008) 271.

[34] A. Jentys, N.H. Pham, H. Vinek, J. Chem. Soc. Faraday Trans. 92 (1996) 3287.

[35] G. Connell, J.A. Dumesic, J. Catal. 105 (1987) 285.

[36] S. Dzwigaj, N. Popovych, P. Kyriienko, J.-M.J.-M. Krafft, S. Soloviev, Microporous Mesoporous Mater. 182 (2013) 16.

[37] G. Centi, G. Golinelli, G. Busca, J. Phys. Chem. 94 (1990) 6813.

[38] T. Hibino, M. Niwa, Y. Murakami, Zeolites 13 (1993) 518.

[39] A. Corma, V. Fornes, L. Forni, F. Marquez, J. Martınez-Triguero, D. Moscotti, J. Catal. 179 (1998) 451.

[40] E. V Makshina, M. Dusselier, W. Janssens, J. Degrève, P.A. Jacobs, B.F. Sels, Chem. Soc. Rev. 43 (2014) 7917.

[41] M. Gao, Z. Liu, M. Zhang, L. Tong, Catal. Letters 144 (2014) 2071.

[42] C. Angelici, M.E.Z. Velthoen, B.M. Weckhuysen, P.C.A. Bruijnincx, Catal. Sci. Technol. $5(2015) 2869$.

[43] O. V. Larina, P.I. Kyriienko, S.O. Soloviev, Catal. Letters 145 (2015) 1162.

[44] V.L. Sushkevich, I.I. Ivanova, E. Taarning, Green Chem. 17 (2015) 2552.

[45] V.L. Sushkevich, I.I. Ivanova, V. V. Ordomsky, E. Taarning, ChemSusChem (2014) 2527.

[46] C.A. Emeis, J. Catal. (1993) 347. 
Fig. 1. Adsorption isotherms of nitrogen at $77 \mathrm{~K}$ for HAlBEA, SiBEA, Nb0.7SiBEA and $\mathrm{Nb}_{2.0} \mathrm{SiBEA}$. For convenience, the dataset for $\mathrm{SiBEA}, \mathrm{Nb}{ }_{0.7} \mathrm{SiBEA}$ and $\mathrm{Nb}_{2.0} \mathrm{SiBEA}$ were shifted upwards along the $\mathrm{Y}$-axis.

Fig. 2. XRD patterns of as-prepared HAlBEA, SiBEA, $\mathrm{Nb}_{0.7} \mathrm{SiBEA}$ and $\mathrm{Nb}_{2.0} \mathrm{SiBEA}$.

Fig. 3. ${ }^{29} \mathrm{Si}$ MAS NMR spectra of as-prepared SiBEA, Nb $0.7 \mathrm{SiBEA}$ and $\mathrm{Nb}_{2.0} \mathrm{SiBEA}$.

Fig. 4. ${ }^{1} \mathrm{H}-{ }^{29} \mathrm{Si} \mathrm{CP}$ MAS NMR spectra of as-prepared SiBEA, $\mathrm{Nb}_{0.7} \mathrm{SiBEA}$ and $\mathrm{Nb}_{2.0} \mathrm{SiBEA}$.

Fig. 5. ${ }^{1} \mathrm{H}$ MAS NMR spectra as-prepared SiBEA, Nb0.7SiBEA and $\mathrm{Nb}_{2.0} \mathrm{SiBEA}_{\text {. }}$

Fig. 6. DR UV-vis spectra of as-prepared $\mathrm{Nb} b_{0.7} \mathrm{SiBEA}$ and $\mathrm{Nb} 2.0 \mathrm{SiBEA}$.

Fig. 7. FTIR spectra of HABEA, as-prepared SiBEA, Nb0.7SiBEA and $\mathrm{Nb}_{2.0} \mathrm{SiBEA}$, outgassed at $573 \mathrm{~K}\left(10^{-3} \mathrm{~Pa}\right)$ for $2 \mathrm{~h}$.

Fig. 8. FTIR spectra of as-prepared $\mathrm{SiBEA}, \mathrm{Nb}_{0.7} \mathrm{SiBEA}$ and $\mathrm{Nb}_{2.0} \mathrm{SiBEA}$.

Fig. 9. FTIR spectra of adsorbed pyridine on $\mathrm{Nb}_{0.7} \mathrm{SiBEA}(\mathrm{A})$ and $\mathrm{Nb}_{2.0} \mathrm{SiBEA}(\mathrm{B})$ catalysts after desorption at different temperatures.

Fig. 10. FTIR spectra of adsorbed 2,6-di-tert-butylpyridine on $\mathrm{Nb}_{0.7} \mathrm{SiBEA}$ and $\mathrm{Nb}_{2.0} \mathrm{SiBEA}$ catalysts after desorption at $423 \mathrm{~K}$.

Fig. 11. Synthesis of unsymmetrical ether in the presence of $\mathrm{Nb}_{0.7} \mathrm{SiBEA}$ and $\mathrm{Nb}_{2.0} \mathrm{SiBEA}$ : change of concentrations of 4-methoxybenzaldehyde (1), 4-methoxybenzyl alcohol (2) and 4methoxybenzyl 1-methylpropyl ether (3). Reaction conditions: aldehyde 1 (1.25 mmol) in 2butanol (4 g), $100 \mathrm{mg}$ of catalyst, $353 \mathrm{~K}$.

Scheme 1. Overall scheme of ethanol conversion to 1,3-butadiene.

Scheme 2. Overall scheme of synthesis of unsymmetrical ether. 


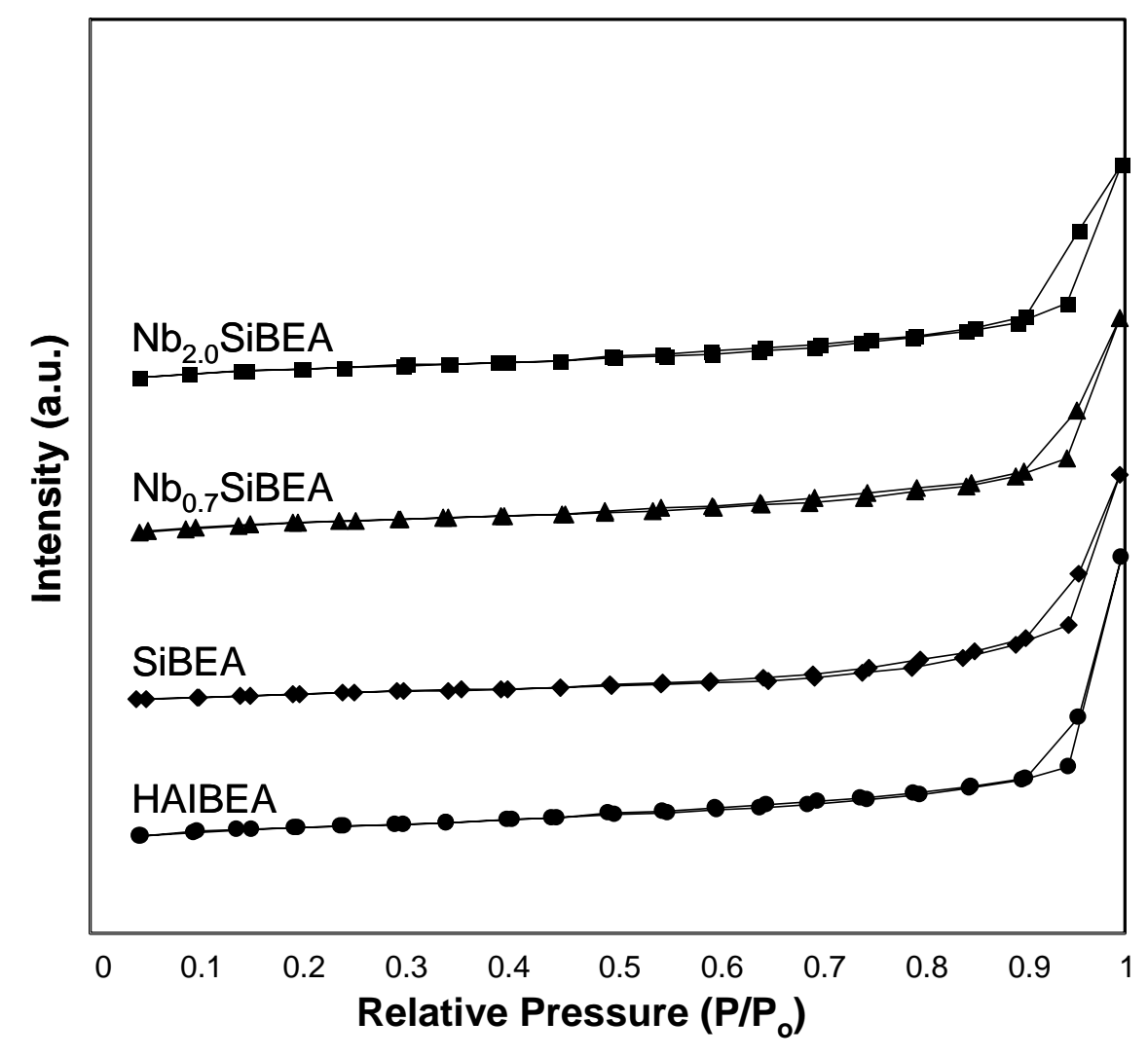

Fig. 1 


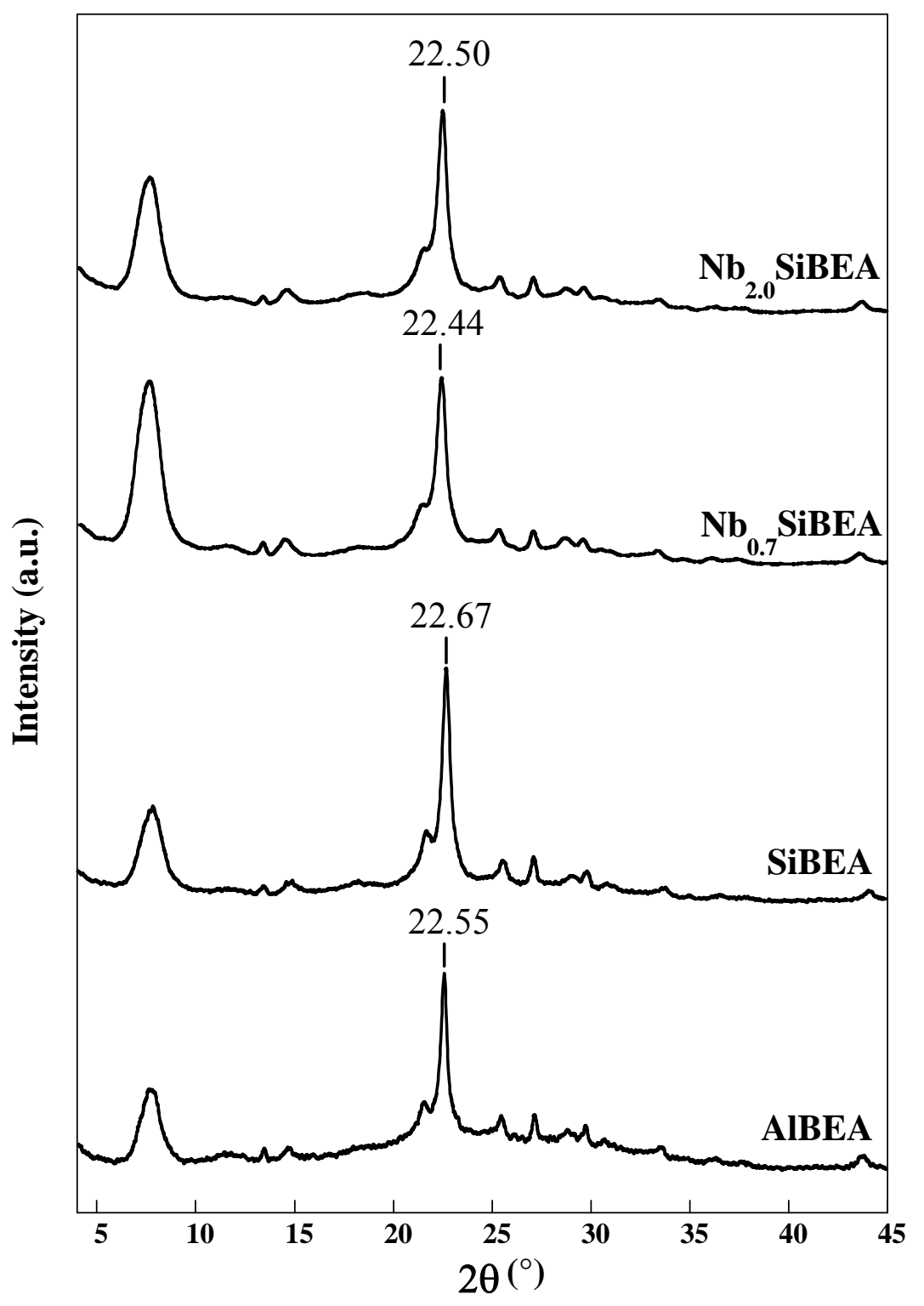

Fig. 2. 


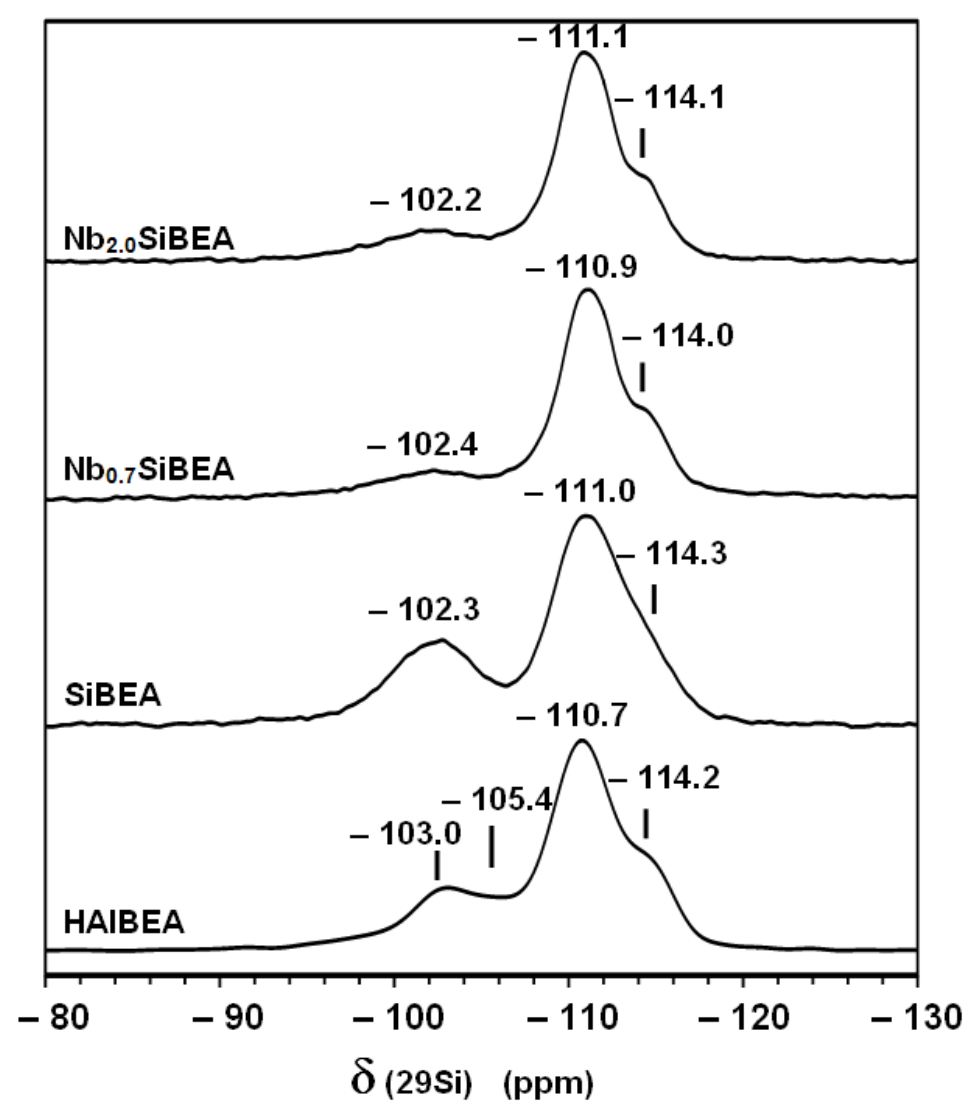

Fig. 3 


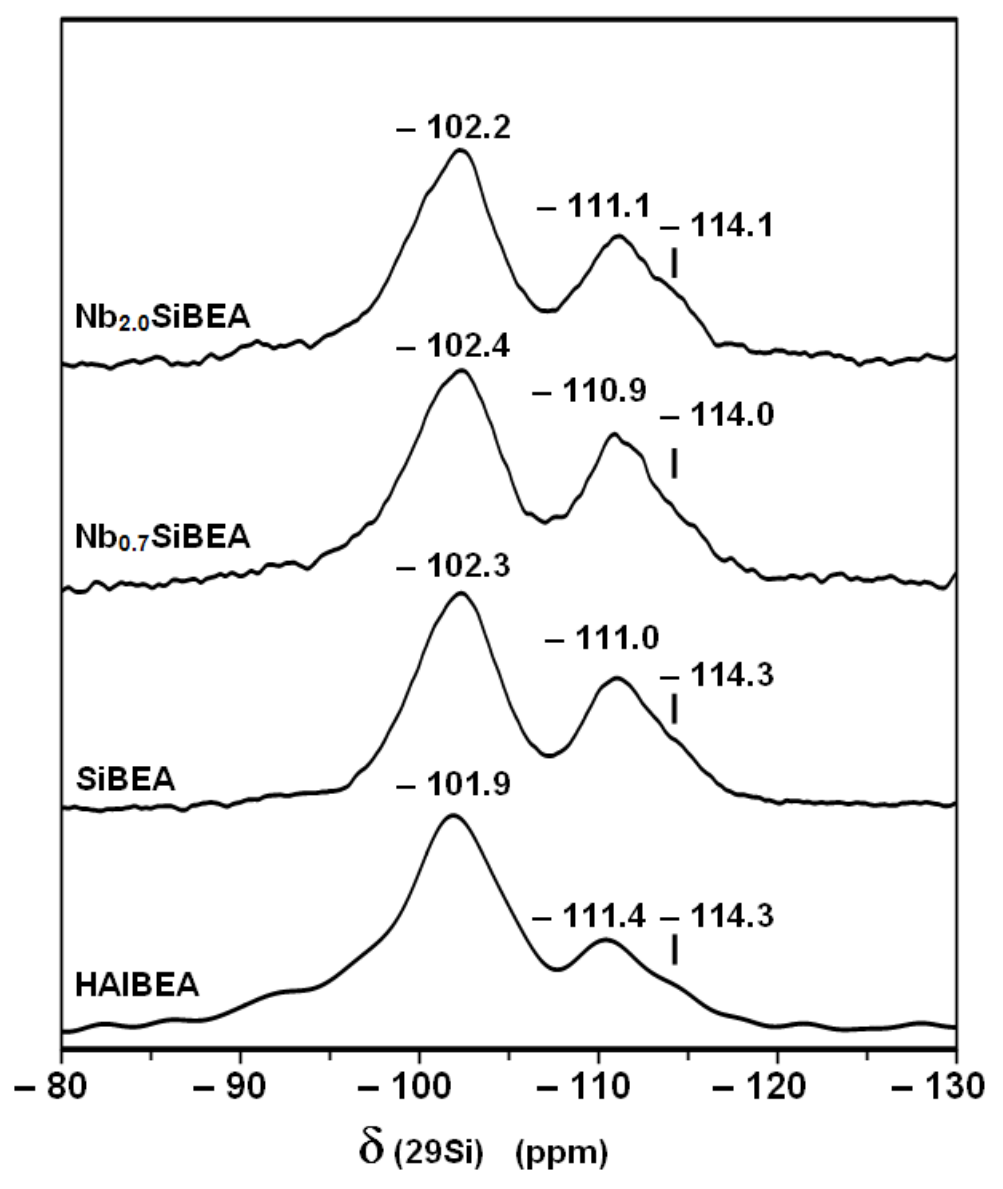

Fig. 4 


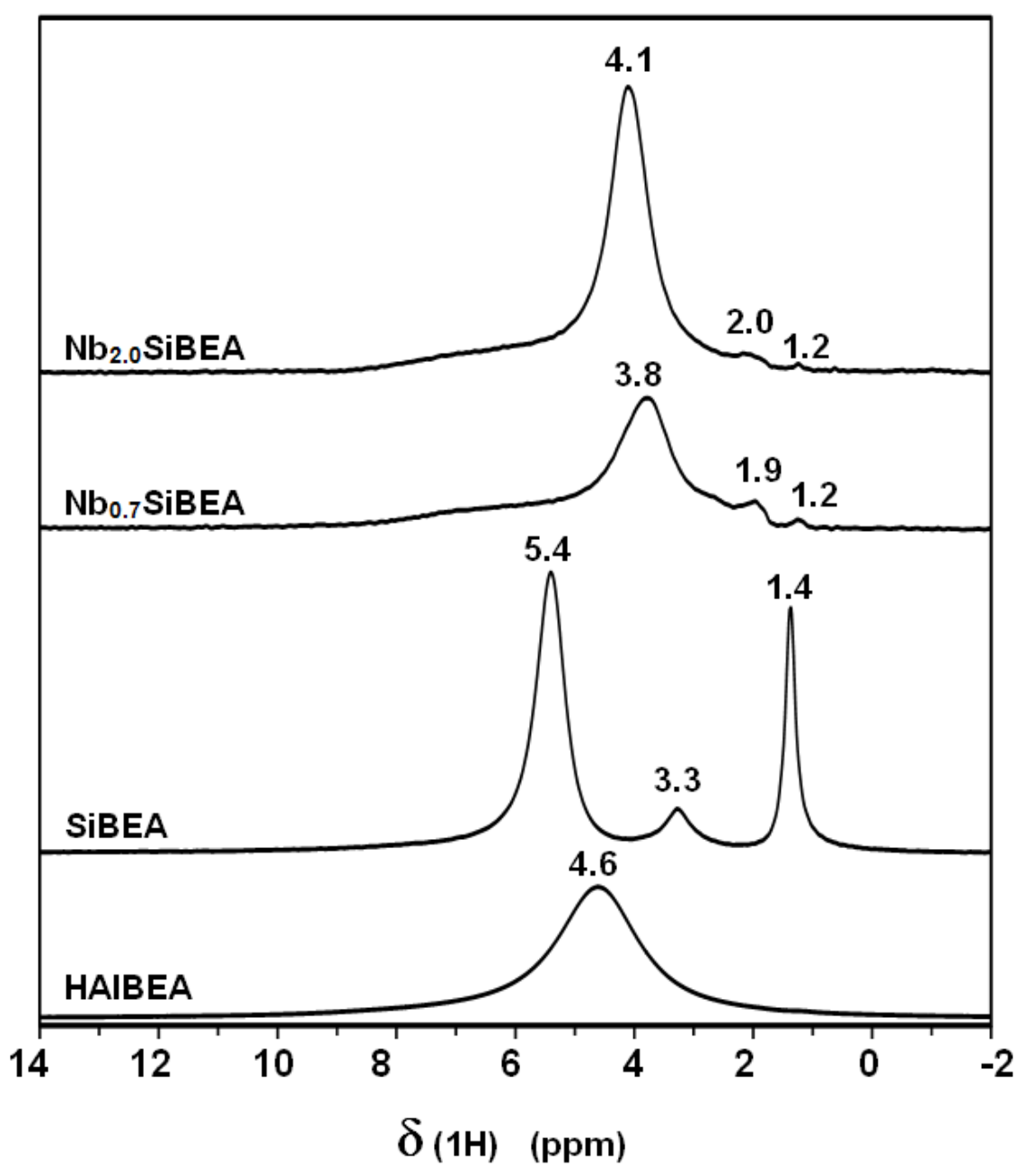

Fig. 5 


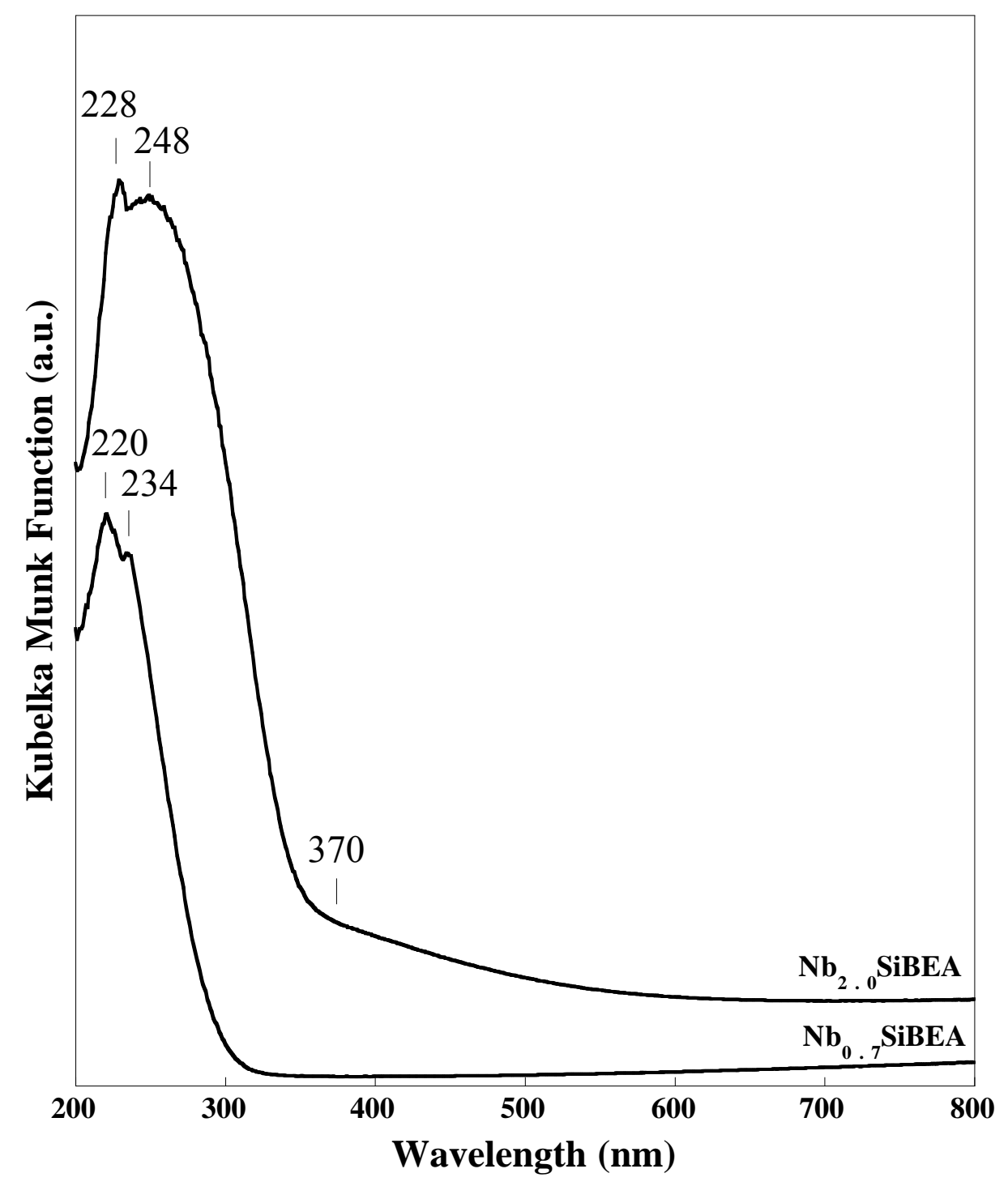

Fig. 6 


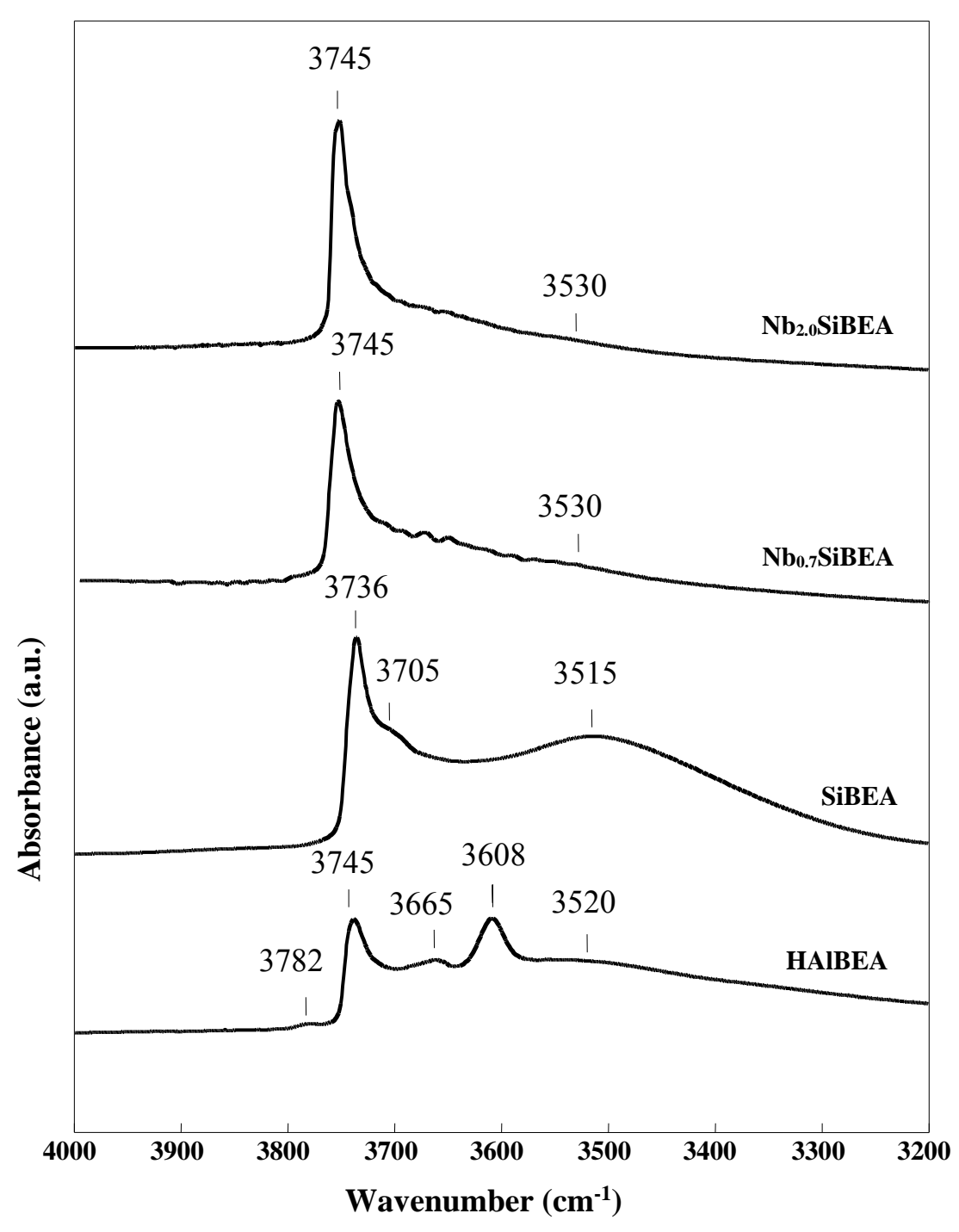

Fig. 7 


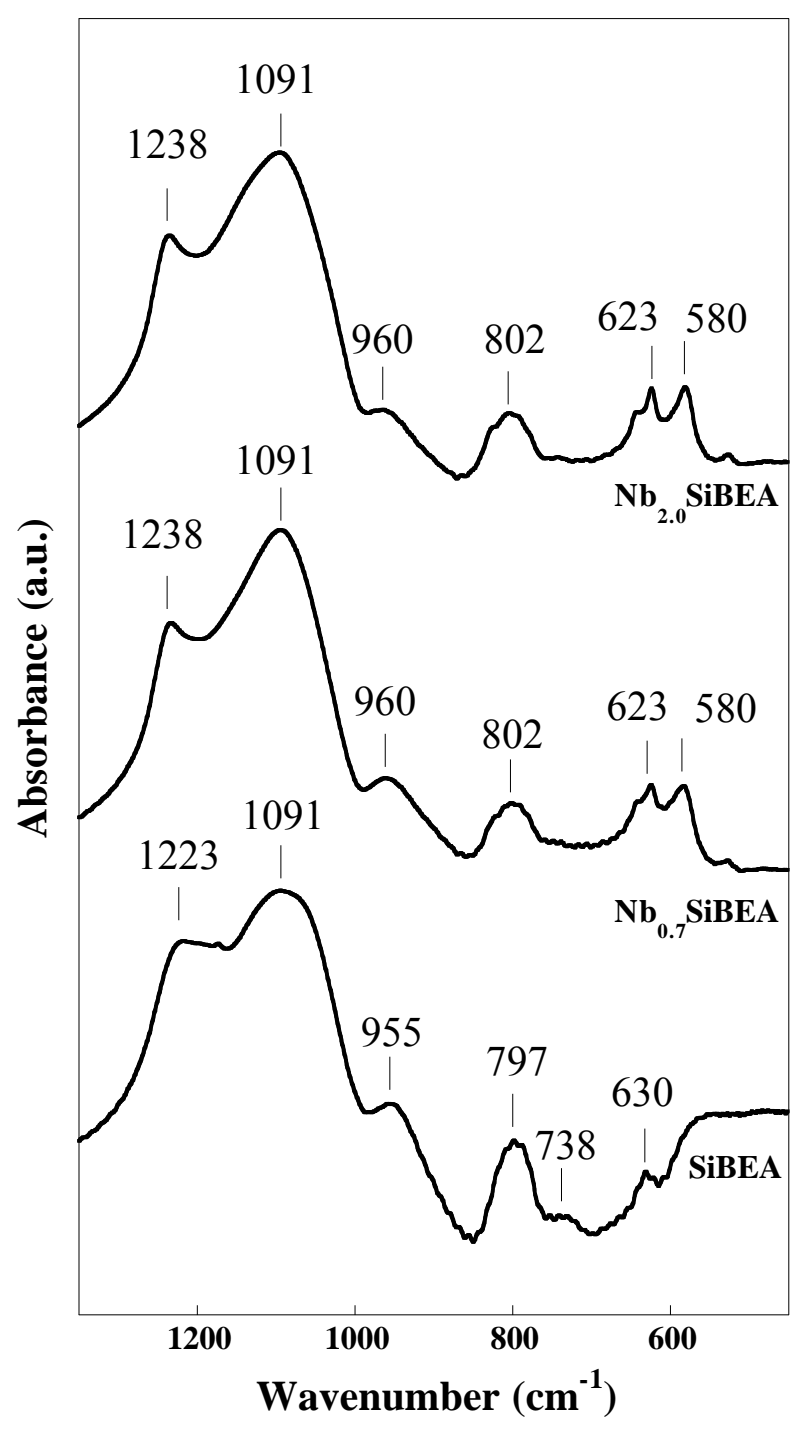

Fig. 8 

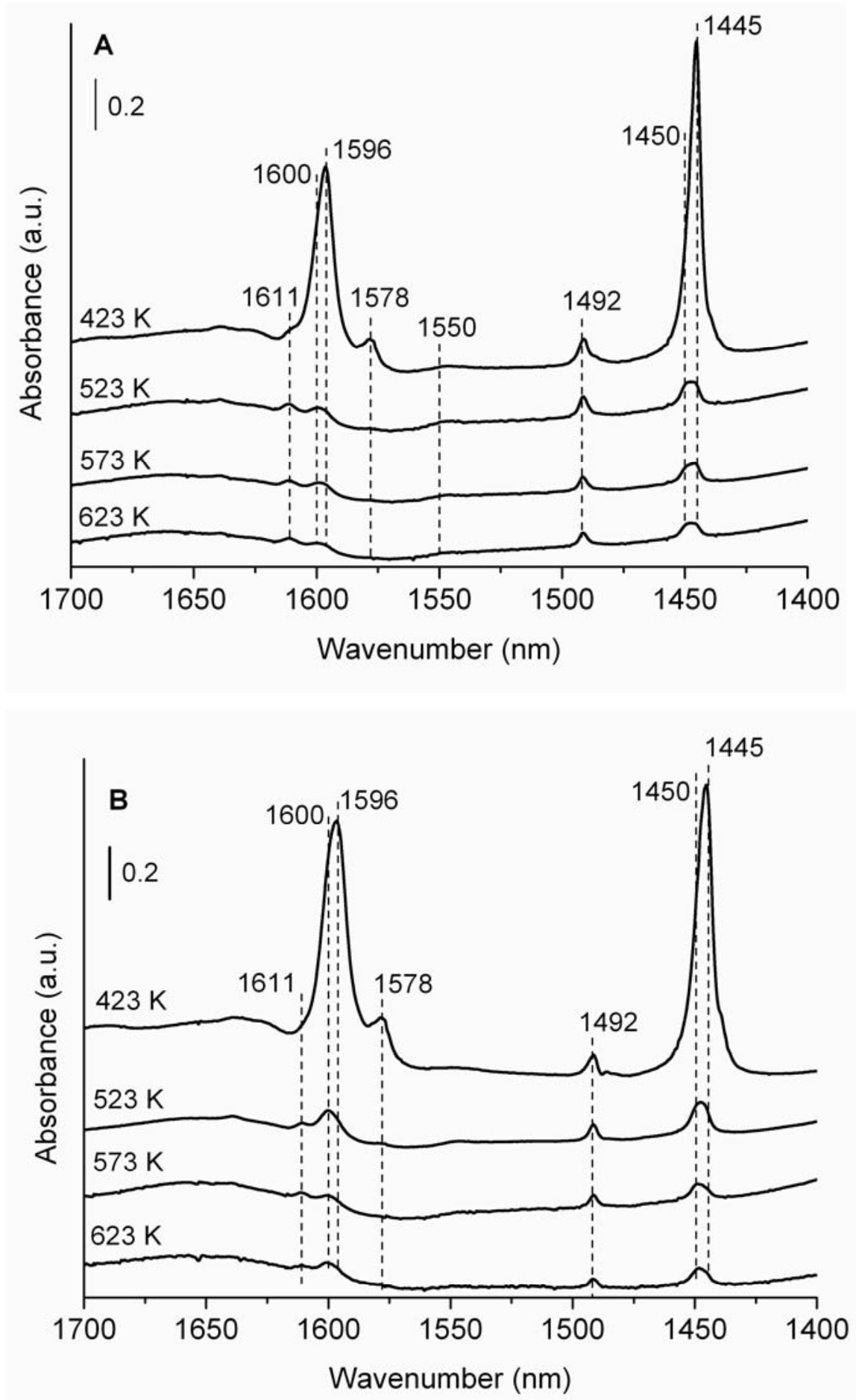

Fig. 9 


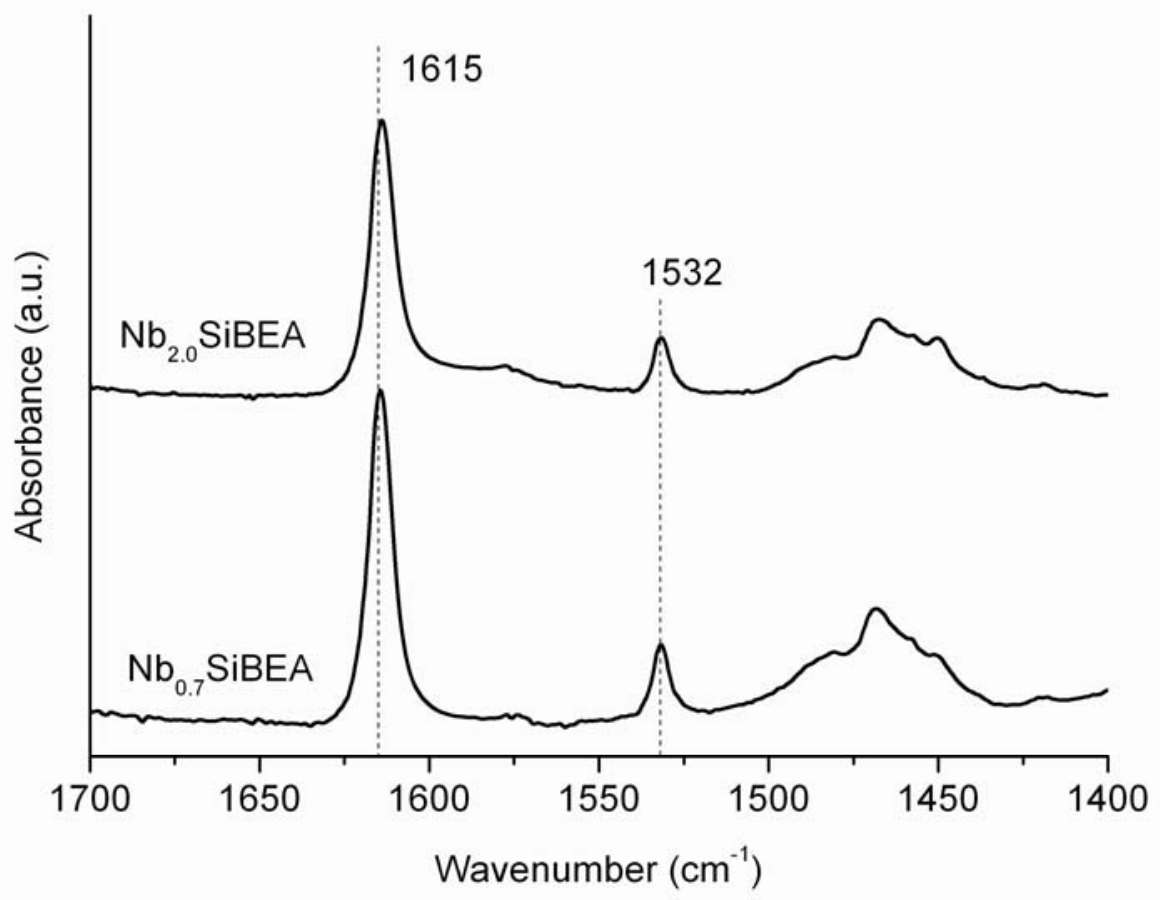

Fig. 10 

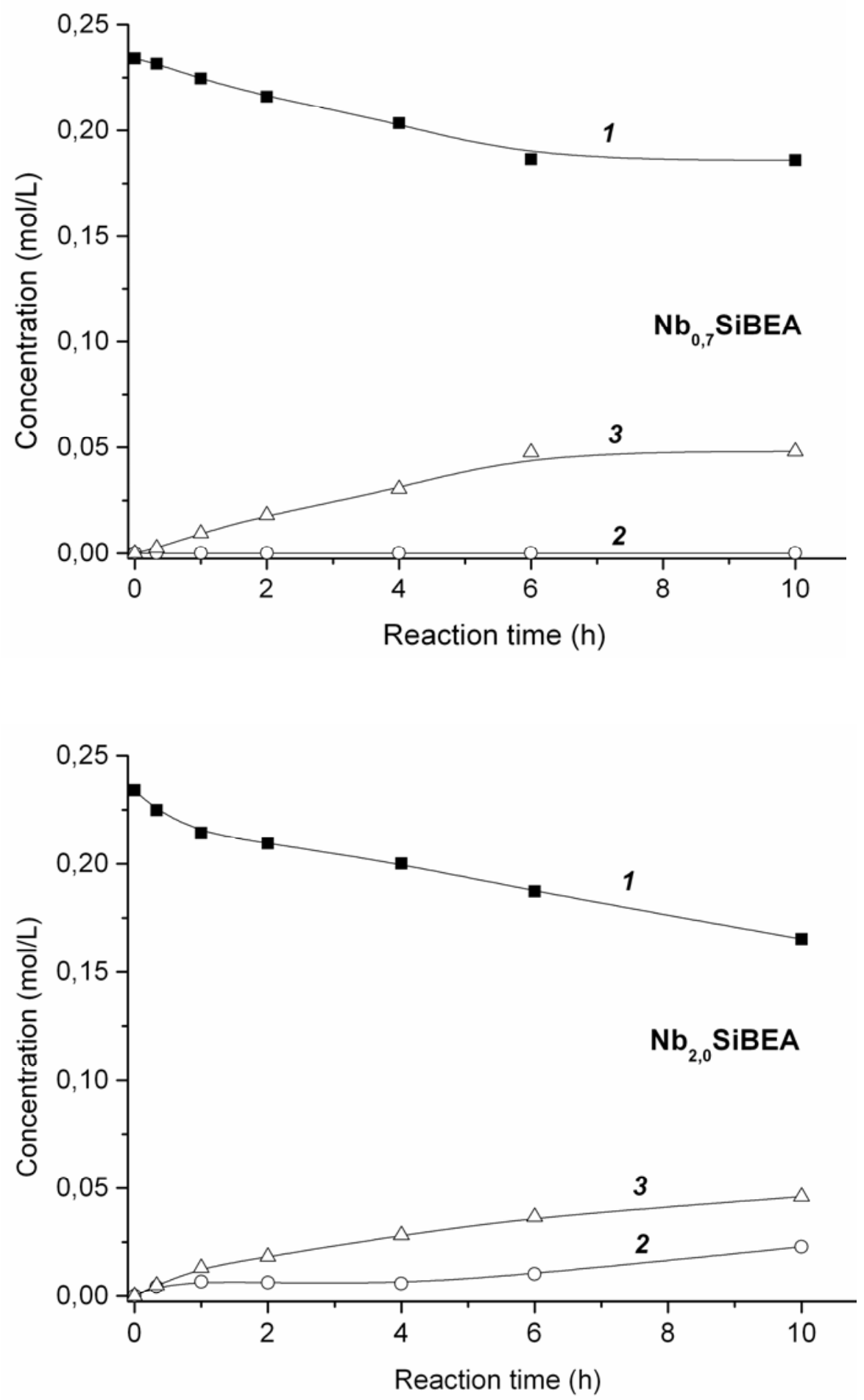

Fig. 11 


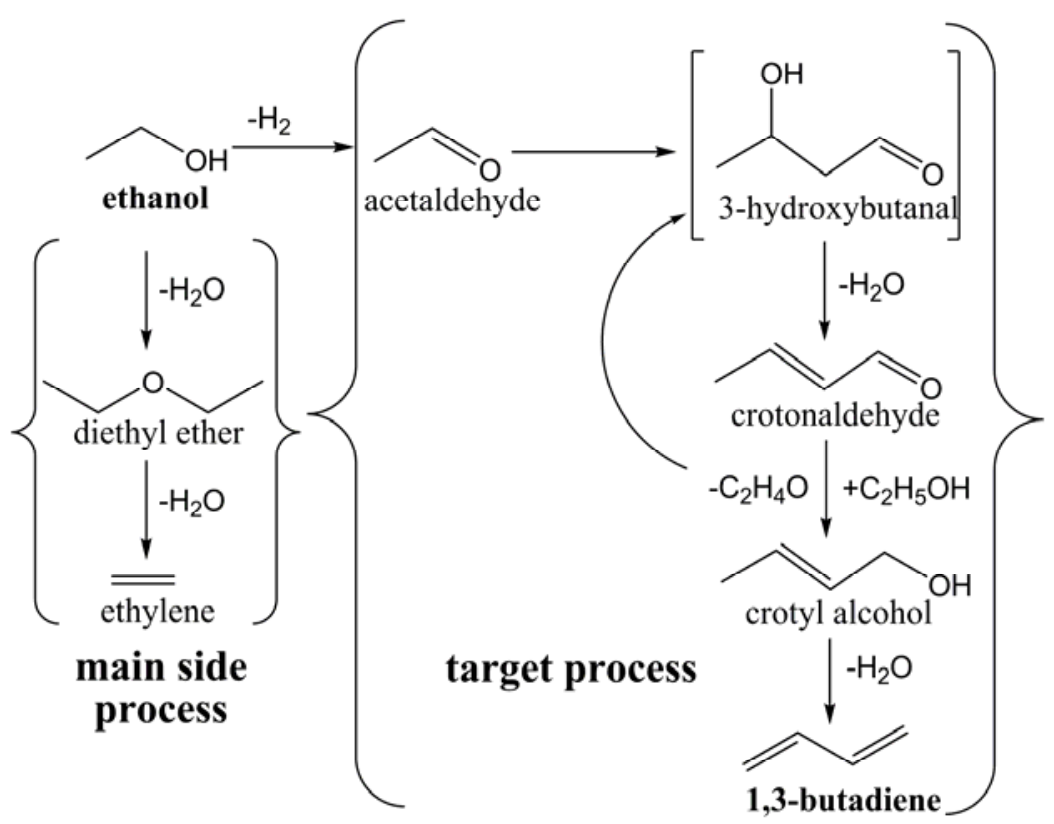

Scheme 1.
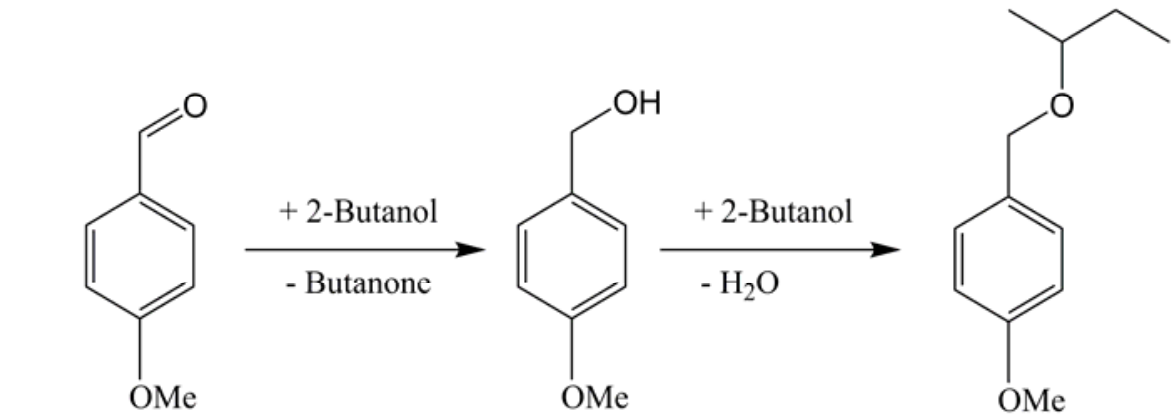

4-methoxybenzaldehyde

4-methoxybenzyl alcohol

4-methoxybenzyl 1-methylpropyl ether

\section{Scheme 2.}


Table 1. Textural properties of zeolite samples.

\begin{tabular}{|l|l|l|}
\hline Sample & $\begin{array}{l}\text { Specific surface area, SBET } \\
\left(\mathrm{m}^{2} \mathrm{~g}^{-1}\right)\end{array}$ & $\begin{array}{l}\text { Micropore volume } \\
\left(\mathrm{cm}^{3} \mathrm{~g}^{-1}\right)\end{array}$ \\
\hline HAlBEA & 489 & 0.20 \\
\hline $\mathrm{SiBEA}$ & 470 & 0.19 \\
\hline $\mathrm{Nb}{ }_{0.7} \mathrm{SiBEA}$ & 460 & 0.20 \\
\hline $\mathrm{Nb}_{2.0} \mathrm{SiBEA}$ & 491 & 0.21 \\
\hline
\end{tabular}


Table 2. Concentration of Lewis acidic sites in $\mathrm{NbSiBEA}^{a}$

\begin{tabular}{|c|c|c|}
\hline Catalysts & $\begin{array}{l}\text { Desorption } \\
\text { temperature }(\mathrm{K})\end{array}$ & $\begin{array}{l}\text { Concentration of Lewis } \\
\text { acidic sites }\left(\mathrm{mmol} \cdot \mathrm{g}^{-1}\right)\end{array}$ \\
\hline \multirow{4}{*}{$\mathrm{Nb}_{0.7} \mathrm{SiBEA}$} & 423 & 40 \\
\hline & 523 & 8 \\
\hline & 573 & 6 \\
\hline & 623 & 4 \\
\hline \multirow{4}{*}{$\mathrm{Nb}_{2.0} \mathrm{SiBEA}$} & 423 & 51 \\
\hline & 523 & 11 \\
\hline & 573 & 5 \\
\hline & 623 & 4 \\
\hline
\end{tabular}

${ }^{a}$ For a quantitative characterization of LAS, the bands at $1450 \mathrm{~cm}^{-1}$ of the FTIR spectra of adsorbed pyridine (Fig. 8) and adsorption coefficient $\varepsilon=2.22 \mu \mathrm{mol} \cdot \mathrm{g}^{-1}$ [46] were used. 
Table 3. Catalytic performance of the NbSiBEA catalysts in ethanol conversion ${ }^{\text {a }}$

\begin{tabular}{|c|c|c|c|c|c|c|c|c|c|}
\hline \multirow[b]{2}{*}{$\mathrm{T}(\mathrm{K})$} & \multirow{2}{*}{$\begin{array}{l}\text { Total } \\
\text { conversion } \\
(\%)\end{array}$} & \multicolumn{7}{|c|}{ Product selectivity $\left(\mathrm{C}_{1} \mathrm{~mol} \%\right)$} & \multirow{2}{*}{$\begin{array}{l}\mathrm{BD} \text { yield } \\
\left(\mathrm{C}_{1}\right. \\
\mathrm{mol} \%)\end{array}$} \\
\hline & & $\mathrm{BD}$ & AA & ethylene & DEE & $\begin{array}{l}\text { butene } \\
\text { isomers }\end{array}$ & $\begin{array}{l}\text { croton- } \\
\text { aldehyde }\end{array}$ & others & \\
\hline \multicolumn{10}{|c|}{$\mathrm{Nb}_{0.7} \mathrm{SiBEA}$} \\
\hline 598 & 42.4 & 27.9 & 16.8 & 42.0 & 12.2 & 0.5 & 0.1 & 0.5 & 11.9 \\
\hline 623 & 74.6 & 22.8 & 11.2 & 56.9 & 8.0 & 0.4 & 0.1 & 0.6 & 17.0 \\
\hline \multicolumn{10}{|c|}{$\mathrm{Nb}_{2.0} \mathrm{SiBEA}$} \\
\hline 598 & 27.1 & 26.0 & 29.6 & 28.0 & 15.6 & 0.3 & 0.1 & 0.4 & 7.1 \\
\hline 623 & 41.9 & 19.6 & 23.5 & 43.5 & 12.9 & 0.2 & 0.1 & 0.2 & 8.2 \\
\hline
\end{tabular}

${ }^{\mathrm{a}} \mathrm{WHSV}=0.8 g_{\text {reagents }} \cdot g_{\text {cat }}{ }^{-1} \cdot h^{-1}$, time-on-stream $=4 \mathrm{~h}$. 
Table 4. TOF values for the NbSiBEA catalysts in the gas-phase process at $598 \mathrm{~K}$

\begin{tabular}{|c|c|c|c|c|c|c|c|c|c|}
\hline \multirow{3}{*}{ Catalyst } & \multicolumn{9}{|c|}{ TOF $\left(h^{-1}\right)$} \\
\hline & \multicolumn{4}{|c|}{ EtOH conversion } & \multicolumn{3}{|c|}{$\begin{array}{l}\text { EtOH/AA } \\
\text { conversion }\end{array}$} & \multicolumn{2}{|c|}{$\begin{array}{l}\text { EtOH/crotonaldehyde } \\
\text { mixture conversion }\end{array}$} \\
\hline & $\mathrm{EtOH}^{\mathrm{a}}$ & $\mathrm{BD}^{\mathrm{b}}$ & $\begin{array}{l}\text { Ethylene } \\
+\mathrm{DEE}^{\mathrm{b}}\end{array}$ & $\begin{array}{l}\text { Dehydro- } \\
\text { genation } \\
\text { products }^{c}\end{array}$ & $\begin{array}{l}\mathrm{EtOH} / \\
\mathrm{AA}^{\mathrm{a}}\end{array}$ & $\mathrm{BD}^{\mathrm{b}}$ & $\begin{array}{l}\text { Ethylene } \\
+ \text { DEE }^{\mathrm{b}}\end{array}$ & $\begin{array}{l}\text { Croton- } \\
\text { aldehyde }^{a}\end{array}$ & $\mathrm{BD}^{\mathrm{b}}$ \\
\hline $\mathrm{Nb}_{0.7} \mathrm{SiBEA}$ & 98 & 27 & 53 & 45 & 89 & 49 & 35 & 75 & 111 \\
\hline $\mathrm{Nb}_{2.0} \mathrm{SiBEA}$ & 22 & 6 & 10 & 12 & 18 & 13 & 3 & 26 & 29 \\
\hline
\end{tabular}

${ }^{\mathrm{a}} \mathrm{mol}$ of reagent(s) reacted/mol of $\mathrm{Nb} /$ hour;

${ }^{\mathrm{b}}$ mol of product(s) produced/mol of $\mathrm{Nb} /$ hour;

c mol of $\mathrm{EtOH}$ dehydrogenated to AA, including acetaldehyde, which was converted to $\mathrm{C}_{4}-$ products $(\mathrm{BD}$, butene isomers and crotonaldehyde). 
Table 5. Catalytic performance of the NbSiBEA catalysts in ethanol/AA mixture conversion ${ }^{\text {a }}$

\begin{tabular}{|c|c|c|c|c|c|c|c|c|}
\hline \multirow{2}{*}{$\mathrm{T}(\mathrm{K})$} & \multirow{2}{*}{$\begin{array}{l}\text { Total } \\
\text { conversion } \\
(\%)\end{array}$} & \multicolumn{6}{|c|}{ Product selectivity $\left(\mathrm{C}_{1} \mathrm{~mol} \%\right)$} & \multirow{2}{*}{$\begin{array}{l}\text { BD yield } \\
\left(C_{1} \text { mol\% }\right)\end{array}$} \\
\hline & & BD & ethylene & DEE & $\begin{array}{l}\text { butene } \\
\text { isomers }\end{array}$ & $\begin{array}{l}\text { croton- } \\
\text { aldehyde }\end{array}$ & others & \\
\hline \multicolumn{9}{|c|}{$\mathrm{Nb}_{0.7} \mathrm{SiBEA}$} \\
\hline 598 & 38.5 & 54.8 & 36.8 & 2.4 & 1.2 & 2.5 & 2.3 & 21.1 \\
\hline 623 & 42.8 & 55.1 & 36.2 & 2.3 & 1.2 & 3.4 & 1.8 & 23.6 \\
\hline \multicolumn{9}{|c|}{$\mathrm{Nb}_{2.0} \mathrm{SiBEA}$} \\
\hline 598 & 22.1 & 70.6 & 11.9 & 2.0 & 1.0 & 11.8 & 2.7 & 15.6 \\
\hline 623 & 25.8 & 53.1 & 29.5 & 3.5 & 1.1 & 10.5 & 2.3 & 13.7 \\
\hline
\end{tabular}

${ }^{\mathrm{a}} \mathrm{WHSV}=0.8 g_{\text {reagents }} \cdot g_{\text {cat }}{ }^{-1} \cdot h^{-1}, \mathrm{EtOH} / \mathrm{AA}=2.7$, time-on-stream $=4 \mathrm{~h}$. 
Table 6. Catalytic performance of the NbSiBEA catalysts in ethanol/crotonaldehyde mixture conversion $^{\mathrm{a}}$

\begin{tabular}{|c|c|c|c|c|c|c|c|c|c|}
\hline \multirow{2}{*}{ Catalyst } & \multirow{2}{*}{$\begin{array}{l}\text { Total } \\
\text { conversion }(\%)\end{array}$} & \multicolumn{8}{|c|}{ Ratio of components in the stream of the reaction products $\left(\mathrm{C}_{1} \%\right)^{\mathrm{b}}$} \\
\hline & & $\mathrm{BD}$ & AA & ethylene & DEE & $\begin{array}{l}\text { butene } \\
\text { isomers }\end{array}$ & $\begin{array}{l}\text { croton- } \\
\text { aldehyde }\end{array}$ & $\mathrm{EtOH}$ & others \\
\hline $\mathrm{Nb}_{0.7} \mathrm{SiBEA}$ & 85.2 & 58.2 & 13.1 & 8.6 & 1.3 & 1.2 & 1.1 & 13.7 & 2.8 \\
\hline $\mathrm{Nb}_{2.0} \mathrm{SiBEA}$ & 66.2 & 43.3 & 13.5 & 5.7 & 1.6 & 0.8 & 2.6 & 31.1 & 1.4 \\
\hline
\end{tabular}

${ }^{\mathrm{a}} \mathrm{WHSV}=0.8 g_{\text {reagents }} \cdot g_{\mathrm{cat}}{ }^{-1} \cdot h^{-1}, \mathrm{EtOH} /$ crotonaldehyde $=2$, time-on-stream $=2 \mathrm{~h}$;

${ }^{\mathrm{b}}$ values are proportional to the yield of a product. 
Table 7. Catalytic performance of the NbSiBEA catalysts in 4-methoxybenzaldehyde/2-butanol conversion $^{\text {a }}$

\begin{tabular}{|l|l|l|l|l|}
\hline \multirow{2}{*}{ Catalyst } & \multirow{2}{*}{$\begin{array}{l}\text { Conversion } \\
\text { of aldehyde 1 (\%) }\end{array}$} & \multicolumn{2}{|l|}{ Product selectivity (\%) } & \multirow{2}{*}{ TON } \\
\cline { 3 - 4 } & & alcohol 2 & ether 3 & \\
\hline $\mathrm{Nb}_{0.7}$ SiBEA & 21 & 0 & 100 & $33^{\mathrm{c}} / 33^{\mathrm{d}}$ \\
\hline $\mathrm{Nb}_{2.0} \mathrm{SiBEA}$ & 29 & 33 & 67 & $16^{\mathrm{c}} / 11^{\mathrm{d}}$ \\
\hline
\end{tabular}

${ }^{a}$ Reaction conditions: aldehyde 1 (1.25 mmol) in 2-butanol (4 g), $100 \mathrm{mg}$ of catalyst, $353 \mathrm{~K}$;

$\mathrm{b}$ after $10 \mathrm{~h}$;

${ }^{\mathrm{c}}$ mol of reacted aldehyde $1 / \mathrm{mol}$ of $\mathrm{Nb}$;

${ }^{\mathrm{d}}$ mol of aldehyde 1 converted to ether $3 / \mathrm{mol}$ of $\mathrm{Nb}$. 
Table 8. Catalytic performance of the NbSiBEA catalysts in 4-methoxybenzyl alcohol/2-butanol etherification $^{\text {a }}$

\begin{tabular}{|l|l|l|l|l|}
\hline \multirow{2}{*}{ Catalyst } & \multicolumn{3}{|l|}{ Conversion of alcohol 2 (\%) } & \multirow{2}{*}{ TON $^{\mathrm{b}}$} \\
\cline { 2 - 5 } & $2 \mathrm{~h}$ & $4 \mathrm{~h}$ & $10 \mathrm{~h}$ & \\
\hline $\mathrm{Nb}_{0.7}$ SiBEA & 93 & 99 & 100 & 292 \\
\hline $\mathrm{Nb}_{2.0}$ SiBEA & 18 & 24 & 37 & 21 \\
\hline
\end{tabular}

${ }^{a}$ Reaction conditions: alcohol 2 (2.5 mmol) in 2-butanol $(4 \mathrm{~g}), 100 \mathrm{mg}$ of catalyst, $353 \mathrm{~K}$;

${ }^{\mathrm{b}} \mathrm{mol}$ of reacted alcohol $2 / \mathrm{mol}$ of $\mathrm{Nb}$. 